\title{
Trends in Wage Inequality in the Netherlands
}

\section{Colja Schneck ${ }^{1}[0$}

Accepted: 21 June 2021 / Published online: 26 July 2021

(C) The Author(s) 2021

\begin{abstract}
In this paper I analyze changes in the wage distribution in the Netherlands. I use a matched employer-employee dataset that covers the population of employees. Wage inequality increases over the period of 2001-2016. Changes in between-firm wage components are responsible for nearly the entire increase. Increases in the variance of workers' skills and increases in worker sorting and worker segregation explain the majority of the rise in the variance of wages. These changes are accompanied by a pattern where variation in educational degree and firm average wages become more correlated over time. Finally, it is suggested that labor market institutions in the Netherlands play an important role in mediating overall wage inequality.
\end{abstract}

Keywords Wage inequality $\cdot$ Pay inequality $\cdot$ Between-firm inequality

JEL Classification $\mathrm{J} 21 \cdot \mathrm{J} 31 \cdot \mathrm{J} 40$

\section{Introduction}

Wage inequality has increased in most industrialized economies since the $1970 \mathrm{~s}^{1}$. The Netherlands has long been considered an exception to this trend, because wage inequality has remained relatively stable, particularly at the highest levels of the wage distribution (Atkinson and Salverda 2005). For instance, Ter Weel (2003) shows that the gap between the 10th and 90th percentile of wages increased by less than $2 \%$ between 1992 and 1998, while Groot and Groot (2011) show that between 2000 and 2008 wage dispersion increased slightly in the upper half of the wage distribution.

However, the literature on Dutch wage inequality in recent years is limited and as I show in this article, the Netherlands also experienced increases in wage dispersion.

\footnotetext{
1 See Acemoglu and Autor (2011) for a detailed overview of changes in labor market trends for the United States and other countries.

Colja Schneck

c.schneck@maastrichtuniversity.nl

1 Department of Organization, Strategy, and Entrepreneurship, Maastricht University, Maastricht, The Netherlands
} 
Figure 1, for example, illustrates the development of various percentiles of real log hourly wages for Dutch full-time male employees, indexed to the base year 2001. The rise in inequality is divided relatively evenly across the wage distribution. From 2001 to 2016, employees in the 80th percentile of wage distribution experienced average wage increases of about $6 \%$, while wages of employees in the 20th percentile increased by about $2.5 \%^{2}$. In comparison to the United States or Germany, increases in wage inequality are small in the Netherlands, at about one fourth to one-third in magnitude. Furthermore, negative wage growth was absent in the lower percentiles.

Several explanations have been proposed for the increase in wage inequality across developed countries. These range from changes in the supply and demand of highskilled individuals (Katz and Murphy 1992; Juhn et al. 1993), trends in the minimum wage, declining unionization or labor reallocation rates (Lee 1999; Card and DiNardo 2002), to the impact of technology (Acemoglu 1998; Autor et al. 2003, 2008) or trade (David et al. 2013; Autor et al. 2015; Helpman et al. 2017). More recently, research has focused on the role of firms in explaining wage inequality. A large fraction of the overall increase in wage inequality can be explained by changes between firms. This trend is common across a number of countries ${ }^{3}$, but evidence for Western European countries besides Germany and the United Kingdom is still scarce.

For instance, Card et al. (2013) show that an increase in the dispersion of firm pay premiums plays an important role in explaining the rise in wage dispersion in Germany over the past decades. Changes in the workforce composition, caused by increases in both worker-sorting ${ }^{4}$ and -segregation ${ }^{5}$, contributed substantially to inequality. High-wage workers became more likely to work not only for high-wage firms, but also with high-wage coworkers. Song et al. (2019) present similar findings for the United States. The rising dispersion of wages is mainly driven by pay differences between firms, especially large firms, and is explained by an increase in the returns to skill and by a rise in worker segregation.

In this paper, I analyze the role of firms and worker composition in the development of wage inequality in the Netherlands. My data are particularly suited for this case, because I use matched employer-employee data that cover the population of workers and firms in the Netherlands over the 2001-2016 period. Furthermore, I observe uncapped wages at the top and bottom of the wage distribution and have information on firms, rather than establishments.

\footnotetext{
2 To compare with Ter Weel (2003), I also report the 90-10 wage gap, which increased by approximately 5\%. Bryson et al. (2016) report an increase of 15 percentage points for the $90-10$ wage gap between 1992 and 2007 in the United States, while Card et al. (2013) show that in western Germany, the 80-20 log wage gap expanded by about 20 percentage points between 1996 and 2009. Wage growth for the workers below the median was negative or stagnant within the same period.

${ }^{3}$ See for instance Davis and Haltiwanger (1991), Autor et al. (2008), Bryson et al. (2016), and Song et al. (2019) for the United States, Helpman et al. (2017) for Brazil, Card et al. (2013) for Germany, and Faggio et al. (2010) for the United Kingdom.

${ }^{4}$ Worker sorting refers to the process by which workers and firms of similar wage level match, for instance, if low-wage workers work for low-wage firms.

${ }^{5}$ Worker segregation is the degree of segregation based on wages. If, for instance, the degree of segregation is low, then low- and high-wage workers are employed in the same firm. If the degree of segregation is high, then low- and high-wage workers are employed in different firms.
} 


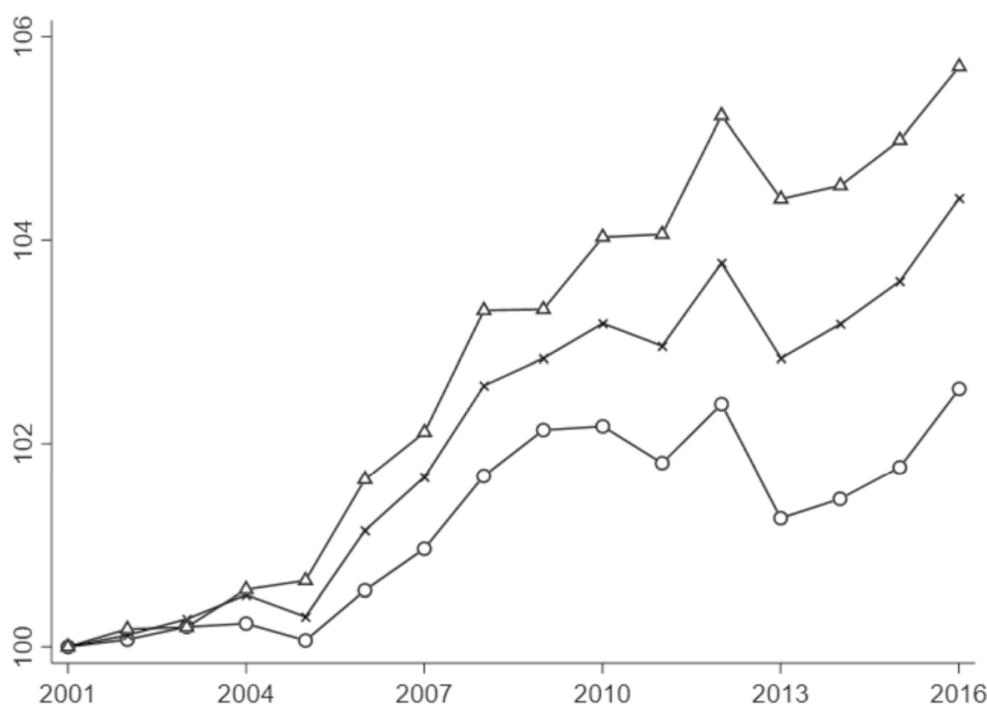

Fig. 1 Trends in percentiles of real log hourly wages for full-time male workers in the Netherlands. Note. This figure displays percentiles of log real hourly wages for full-time male workers in the Netherlands. $(\triangle)$ 80th percentile; $(\times)$ 50th percentile; (o) 20th percentile. Percentiles are calculated by subtracting the 2016 percentile from the 2001 percentile, multiplied by 100

In general, wage inequality can increase because wages within firms are more dispersed, or because some firms pay better wages. Therefore, I decompose wage dispersion across firms into within-firm and between-firm components. Changes in the average wage that firms pay are responsible for nearly the entire increase in overall wage inequality, especially in large firms. To better understand the drivers of wage dispersion, I estimate the two-level fixed effects model introduced by Abowd et al. (1999) and follow the implementation of Card et al. (2013). I use the estimated components to decompose the changes in the variance of wages. Increases in wage dispersion are primarily explained by a widening skill premium. Furthermore, I provide new evidence on changes in workforce composition. I show that the distribution of workers across firms became increasingly polarized by their educational level. The share of employees with low and medium levels of education increased in low-wage firms, whereas highly educated workers increasingly tend to work at high-wage firms. Finally, I argue that the effects of labor market institutions must be examined more closely, particularly collective agreements and minimum wages on wage dispersion, because the system of industrial relations plays an important role in determining aggregate outcomes. 
The remainder of this article is organized as follows. In Sect. 2, I provide information on the Dutch labor market. Section 3 describes the data and Sect. 4 discusses the development of wage inequality in the Netherlands. Section 5 decomposes the change in wage dispersion into components related to changes between and within firms. In Sect. 6, I describe the estimation of the econometric model and decompose the changes in wage dispersion into its components. Section 7 discusses possible sources of the rise in wage dispersion. Section 8 concludes.

\section{The Dutch Labor market}

The Dutch labor market in the post-war period of the late 1940s and 1950s was characterized by economic recovery. Strong growth, labor shortages, and immigration mainly from Mediterranean countries marked the 1960s, followed by a slow-down in growth and increases in unemployment in the 1970s. The late 1970s and early 1980s were a period of crisis, characterized by high levels of unemployment and structural changes, such as the pegging of the Dutch Guilder to the German Mark, forming a monetary union with the erstwhile West Germany. These developments created the need for more flexible labor markets. Simultaneously, wage bargaining in Europe shifted towards the Anglo-Saxon model with a larger emphasis on contingent reward (for instance, performance-related pay and share option schemes), more flexible working practices, fewer long-term working relationships, lower employment protection, and less focus on binding collective agreements (Ter Weel 2003). The government lost formal influence in wage determination when contract negotiations moved from the national to the industry level ${ }^{6}$.

The late 1990s and early 2000s were characterized by strong declines in unemployment and strong growth in the labor force, labor market participation, and part-time work. For instance, the workforce increased from 6.9 million individuals in 1990 to 8.3 million individuals in 2001, and to 9.0 million individuals by 2016 . Simultaneously, labor participation increased, especially of women, from $53 \%$ in 1990 to $65 \%$ in 2001 and $75 \%$ in 2016 (OECD 2020a). However, since 2001, the total number of hours worked has been decreasing, due to increasing levels of parttime work (Van den Berge et al. 2014; CPB 2017). The Netherlands has the highest rate of part-time jobs in OECD countries. Men typically work full-time $(\approx 75 \%)$, while the majority of women $(\approx 75 \%)$ works part-time (Hartog and Salverda 2018).

Despite the liberalization of the Dutch labor market in the 1980s, it is still characterized by a highly coordinated wage-setting system. Its labor market institutions emphasize consultation, cooperation, and consent between different economic and political actors. Consultation at the national level is facilitated by two bodies: the Social and Economic Council (SEC) and the Foundation of Labor (FOL). The tripartite SEC is the advisory body of the Dutch government and consists of representatives from employer and employee organizations, as well as representatives of the Dutch central bank and CPB Netherlands, the Bureau for Economic Policy Analysis.

\footnotetext{
6 See Teulings and Hartog (1997) for a detailed analysis of the Dutch labor market.
} 
The bipartite FOL is a forum for consultation between employers' confederations and trade union confederations. It functions as an informal channel alongside the SEC to advise the government on labor market policies.

On this basis, flexible arrangements were bargained that govern the regulation of stock markets; wages and working conditions; vocational training, pensions, and social security; and collective dismissals (Delsen and Poutsma 2005). Collective agreements are bargained at the industry level and cover all workers within a sector, regardless of union membership. However, some firms opt out of these agreements and negotiate their own agreements with trade unions. Similar to Anglo-Saxon labor markets, union density has decreased since 2001; however, collective coverage has remained relatively stable over time and covered about $80 \%$ of employees in 2016 (OECD 2020b).

\section{Data}

Data are obtained from Statistics Netherlands. At the worker level, the worker records (BAAN files) contain yearly information on jobs, employment and unemployment spells, wages, and working hours of the population of salaried workers in the Netherlands ${ }^{7}$. I complement these data with information on worker demographics from the municipal administration records (GBA files) such as age and gender. Using a common identifier, datasets can be linked at the individual and firm levels. To ensure that the sample only includes workers with a sufficient attachment to the labor market, I impose several restrictions. I eliminate observations with missing entries on the firm identifier, workers younger than 25 years or older than 65 years, and those who have reported earnings of less than $90 \%$ of the Dutch minimum wage or an hourly wage above $€ 500^{8}$. Workers who worked full-time less than a quarter year are excluded (in 2015, this corresponds to thirteen 40-hour work weeks at $€ 8.85$ per hour). I also drop workers who are employed under the social workplace act or who are employed as apprentices. If a worker has multiple jobs, I only consider the one that provides the main source of income in a year. If a worker switches employers within a year, I only consider the job at which the individual worked the longest. Hourly wages are calculated by dividing the yearly gross wage by the hours worked. All wage information is deflated to constant 2015 prices using the consumer price index provided by CBS (CBS Netherlands). One disadvantage of my data is that I do not have information on the type of occupation and only observe education for a fraction of all workers.

For my main analysis, I focus on the hourly wages of Dutch men, since the majority of Dutch women work part-time (about $75 \%$ of women work part time), which may raise concerns about selectivity bias. Furthermore, I restrict my analysis to firms with at least ten employees to ensure that my within-firm statistics are

\footnotetext{
7 Monthly data on wages is only available from 2006 onwards via the POLIS/SPOLIS datasets.

${ }^{8}$ I observe uncapped wages but restrict hourly wages at $€ 500$ per hour, because there are some unreasonably large values, which I believe are input errors.
} 
informative. I also exclude firms and workers in firms in the public services and educational sectors because organizations in these sectors are not firms in the traditional sense.

Table 1 presents summary statistics for my sample before and after applying the restrictions described above. After imposing restrictions on age, wage, gender, and working hours, I arrive at 23.6 and 23.1 million individual-year observations for the 2001-2008 and 2009-2016 periods, respectively. For all figures and tables presented in this article, as well as for the estimation of the two-level fixed effects model that I will describe in more detail below (Sect. 6.1), I only consider the largest connected set of workers, identified by worker flows between firms ${ }^{9}$. Thus, for the 2001-2008 and 2009-2016 periods, I have 23.1 and 22.6 million individual-year observations as well as 3.78 and 3.73 million unique workers, respectively.

\section{Trends in Wage Inequality}

Figure 2 shows several measures of wage dispersion for Dutch full-time male workers: The standard deviation of wages, the gap in log wages between the 80th and 20th percentile, the gap between the 80th and 50th percentiles, and the gap between the 50th and 20th percentile. For the sake of comparability, I normalize the percentile gaps by dividing the respective gaps by the gaps of the standard normal distribution ${ }^{10}$.

As can be observed in Fig. 2, the normalized gaps and the standard deviation follow a similar trend, although there are differences in their level. The standard deviation of wages increased by $4 \log$ points between 2001 and 2016, whereas the 80-20 wage gap increased by $5 \log$ points. The 80-50 and 50-20 wage gap both rose by 6 log points. Wage dispersion increases relatively evenly across the distribution and, in contrast to other countries, is not heavily influenced by increases in the upper wage percentiles.

Figure 3 displays the normalized 80-20 real log wage gap for alternative sample definitions. I compare the results for full-time male workers, full-time female workers, all men (full- and part-time workers), and all women. Including part-time male workers increases the effect on wage inequality slightly. Wage inequality among fulltime female workers is lower than for men but increased at a similar rate. Including part-time female workers decreases wage inequality for all female employees. The 80-20 log wage gap declined by 3 percentage points, from about $45 \%$ in 2001 to $42 \%$ in 2016 . However, overall, the observed trends suggest that for the majority of labor market participants, wage inequality increased within the last two decades.

\footnotetext{
9 The largest connected set refers to the group of firms connected by worker mobility. See Sect. 6.1 for details.

10 I follow Card et al. (2013) and construct the normalized 80-20 gap by dividing it by $\Phi^{-1}(0.8)-\Phi^{-1}(0.2)=1.683$, where $\Phi($. $)$ represents the CDF of the standard normal distribution.
} 
Table 1 Summary statistics for sample and largest connected set

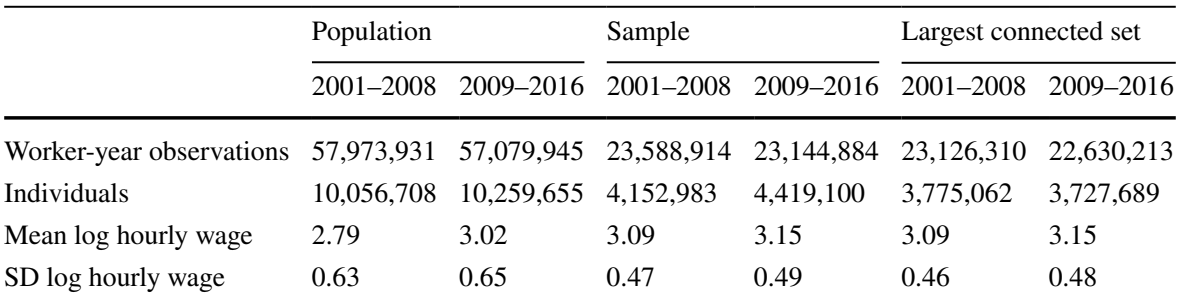

Population refers to the population of workers without imposing any restrictions on gender, age, or wages. Sample refers to the sample of employed men aged 25-65 years in the 2001-2016 period, where employed is defined as having reported earnings that correspond to at least $90 \%$ of the Dutch minimum wage, or working at least thirteen 40-hour weeks or 520 hours per year for the year's minimum wage. The largest connected set refers the group of firms connected by worker mobility (see Abowd et al. (2002) for details). Mean and SD wage refer to the mean and standard deviation of log real hourly wages, respectively

\section{Wage Dispersion Within- and Between-Firms}

In the previous section, I show that for most employees, wage dispersion has increased. I now examine the role of firms more closely. Some recent articles argue that the majority of the rise in wage variance is accounted for by a widening gap between the wages that firms pay (Card et al. 2013; Bryson et al. 2016; Song et al. 2019). In this section, I test whether workplace heterogeneity explains the recent increase. Following Song et al. (2019), I present three pieces of evidence. First, I decompose the variance of wages into between- and within-firm components. I then examine how the relationship between individual and firm-average wages developed across the earnings distribution. Finally, I conduct a counterfactual analysis, which allows for ascertaining how wage inequality would have developed, if within-firm dispersion or between-firm dispersion had remained unchanged over the 2001-2016 period.

My results from these three approaches confirm that between-firm wage dispersion, that is, a rise in the dispersion of average firm wages, plays an important role in explaining the rise in overall wage inequality.

\subsection{Variance Decomposition of Wages}

I now present a simple approach to decompose the variance of log wages into between- and within-component elements. Let $y_{t}^{i, j}$ be the log wage of worker $i$ in firm $j$ in year $t$. Individual wages can be dissected into two components:

$$
y_{t}^{i, j}=\bar{y}_{t}^{j}+\left[y_{t}^{i, j}-\bar{y}_{t}^{j}\right]
$$

where $\bar{y}_{t}^{j}$ is the mean wage of firm $j$ in year $t$. Following Song et al. (2019), the variance of wages can be decomposed as follows: 


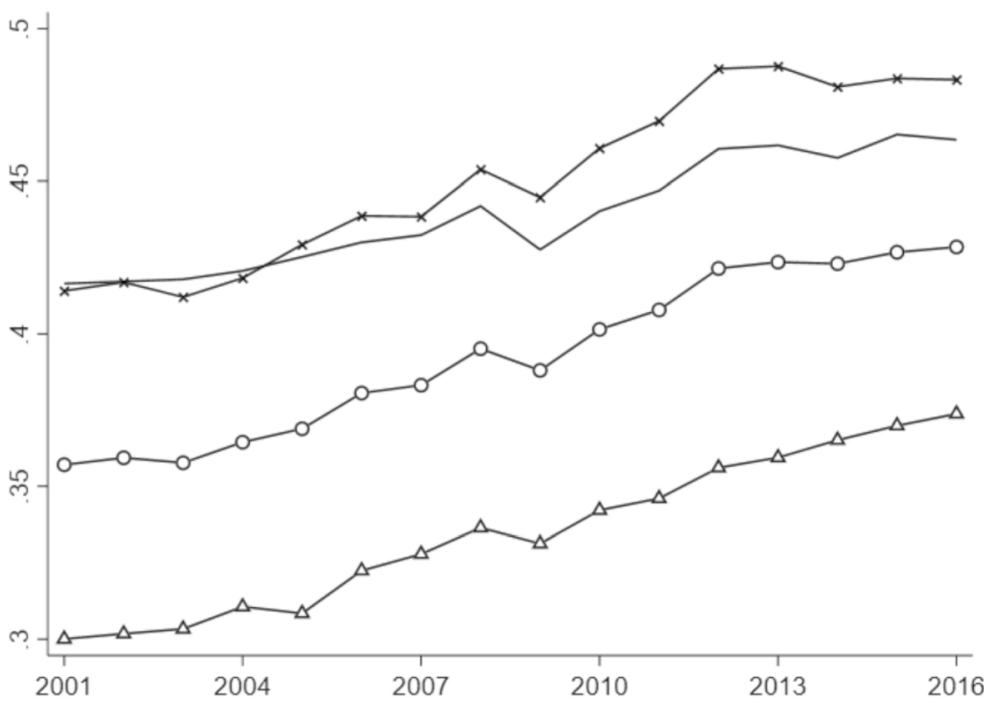

Fig. 2 Trends in wage dispersion for Dutch full-time male workers. Note. This figure displays different log wage gaps for Dutch full-time male workers: (-) Standard Deviation of log wages; $(\times)$ 80-20 log wage gap; (o) 80-50 log wage gap; $(\triangle$ ) 50-20 log wage gap. Measures of dispersion are estimated using real log hourly wages. Normalized percentile gaps are constructed by dividing differences in percentiles by the corresponding differences of the standard normal variate

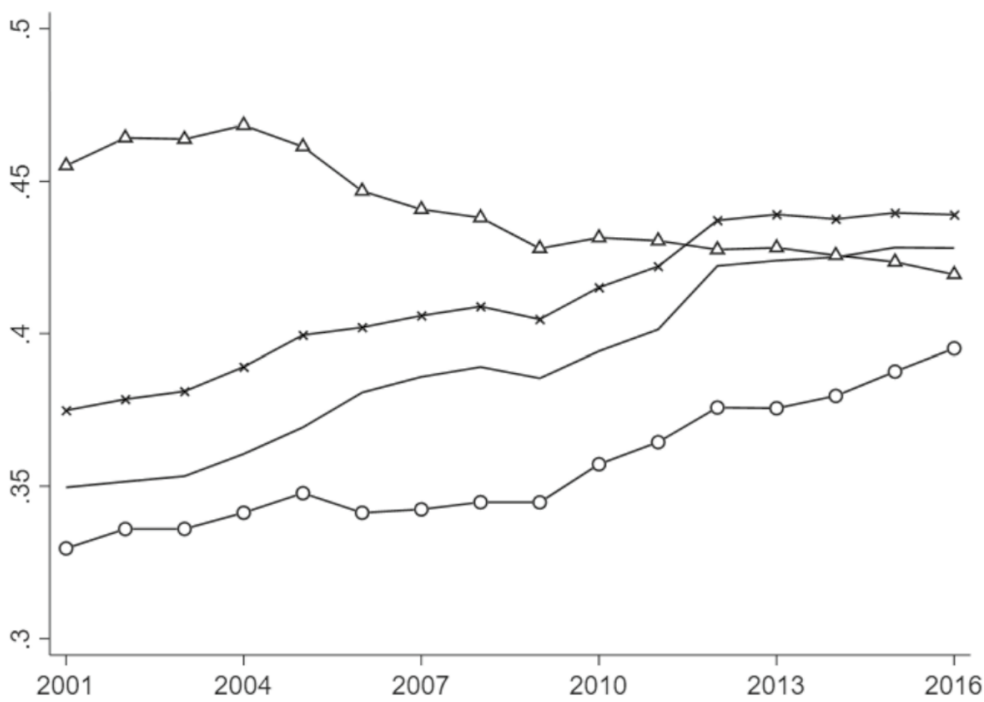

Fig. 3 Trends in wage dispersion alternative samples of workers. NOTE. This figure displays the normalized 80-20 real log wage gap for different samples of Dutch workers: (-) Full-time male workers; $(\times)$ Part-time and full-time male workers; (o) Full-time female workers; $(\triangle)$ Part-time and full-time female workers. Normalized percentile gaps are constructed by dividing differences in percentiles by the corresponding differences of the standard normal variate 


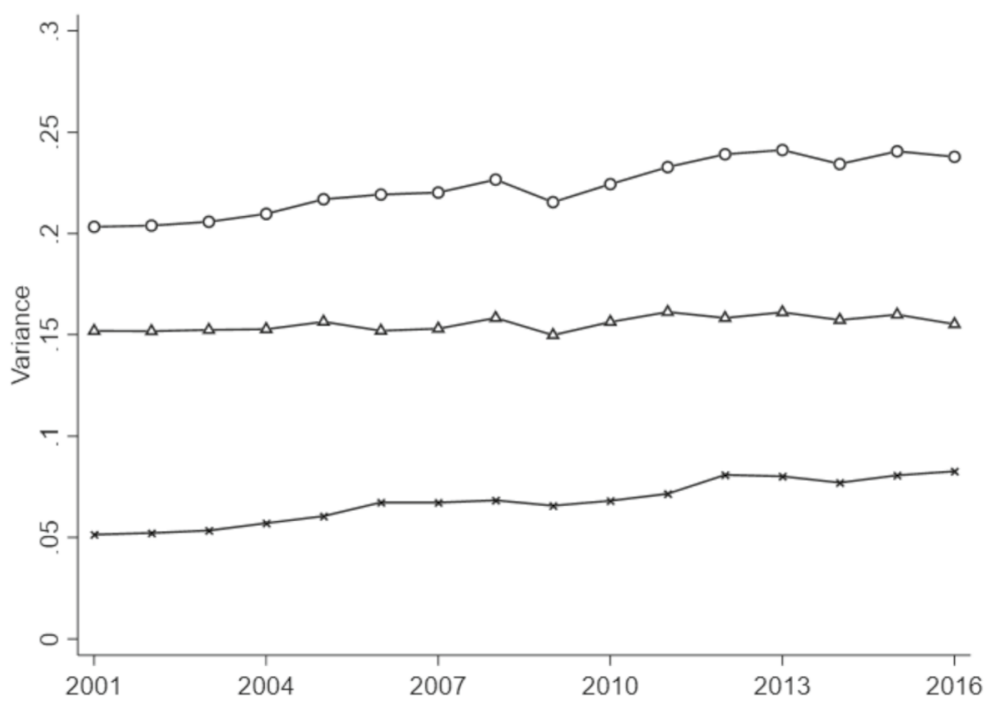

Fig. 4 Variance decomposition of real log hourly wages. Note. This figure displays the results of the variance decomposition of Eq. (1). (o) Overall wage variance $(\triangle)$ Within-firm variance; $(\times)$ Betweenfirm variance. I present results for firms with more than ten male employees and exclude individuals employed in public services and education

$$
\operatorname{var}\left(y_{t}^{i, j}\right)=\underbrace{\operatorname{var}_{j}\left(\bar{y}_{t}^{j}\right)}_{\text {Between-Firm Variance }}+\underbrace{\sum_{j} w_{j} \times \operatorname{var}\left(y_{t}^{i, j} \mid i \in j\right)}_{\text {Within-Firm Variance }}
$$

Based on Eq. (2), the total dispersion of wages in the economy can be decomposed into between-firm wage dispersion, measured as the variance of firm average wages across firms, and within-firm dispersion of employee wages, weighted by the number of employees of firm $j$, over the total number of employees in the sample, denoted as $w_{j}{ }^{11}$

Figure 4 displays the results of the decomposition from Eq. (1). Overall, the variance of wages increases by $4 \log$ points between 2001 and 2016 . The overall 4-point rise is almost completely caused by an increase of the between-firm component, whereas within-firm wage dispersion is nearly constant across my observation period. This decomposition shows that between-firm wage changes account for $90 \%$ of the increase in overall wage inequality ${ }^{12}$.

Song et al. (2019) show that firm size plays an important role in the development of between- and within-firm wage inequality. Therefore, I conduct the same decomposition as above, but distinguish by firm size. I divide the sample into smaller and

\footnotetext{
11 For simplicity, we abstract from the covariance terms here.

12 Overall variance of wages increased from 0.2033 in 2001 to 0.2379 in 2016 . Within- and betweenfirm wage variances increased from 0.1518 and 0.0514 in 2001 to 0.1552 and 0.0827 in 2016 , respectively. This yields a share of 0.098 for within- and 0.902 for between-firm wage variance of the overall variance change.
} 
medium-sized firms, with more than 10 but less than 5000 employees, and large firms with more than 5000 employees. In Figs. 5a and b, I present the results. In large firms, the share of the between-firm wage component accounts for $15.6 \%$ of the total wage dispersion in 2001 and for $34.3 \%$ in 2016. In small to medium-sized firms, it accounted for $26.0 \%$ and $34.6 \%$ of the total in 2001 and 2016 , respectively. Workers in large firms (5000+ employees) account for approximately $7 \%$ of the total employment but $15 \%$ of the total increase in inequality ${ }^{13}$ Overall, my findings are in line with those of Song et al. (2019). Wage differences between large firms are disproportionally responsible for the rise in total wage inequality, although they are of weaker magnitude than in the Unites States.

\subsection{Counterfactual Wage Distribution}

To determine how wage inequality would have developed if either between- or within-firm wage dispersion had remained at the levels observed in 2001, I follow Autor et al. (2008) and Song et al. (2019) and estimate a counterfactual distribution for the distribution of wages. For a detailed explanation of the procedure, please see section A in the "Appendix".

Results of the decomposition are shown in Fig. 6. The solid black line displays average changes in individual worker wages by percentile. The dashed line represents the wage decomposition if only changes in within-firm inequality had occurred. As can be observed, these are close to zero but tend to decrease dispersion in the lower percentiles and increase dispersion in the higher percentiles. The dotted line displays the wage distribution if only between-firm changes had taken place. Note that nearly the entire increase in wage dispersion is driven by between-firm changes.

My results are consistent with the findings from the variance decomposition and the analysis of changes in the distribution of individual and firm-average wages in Sect. 5.1. The overall rise in wage inequality in the Netherlands between 2001 and 2016 is almost entirely explained by changes in the average wages that firms pay.

\footnotetext{
${ }^{13}$ Total between-firm variance at time $t, B_{t}$ can be decomposed into the within-component of small firms $B_{s t}$ and the within-component of large firms $B_{l t}$. Both components are weighted by their share in total employment, $f_{s t}$ and $f_{l t}$, respectively. This yields $B_{t}=f_{s t} B_{s t}+f_{l t} B_{l t}$. To compute the amount that small and large firms contributed to the overall rise in between-firm inequality, I decompose $B_{2}-B_{1}=f_{s 2}\left(B_{s 2}-B_{s 1}\right)+f_{l 2}\left(B_{l 2}-B_{l 1}\right)+R$, where $R$ is a term that includes changes in the share of total employment. Small firms, represented by the first term of the equation, account for $83 \%$ of the overall change in between-firm wage dispersion while large firms, represented by the second term, account for $15 \% . R$ accounts for the remainder.
} 


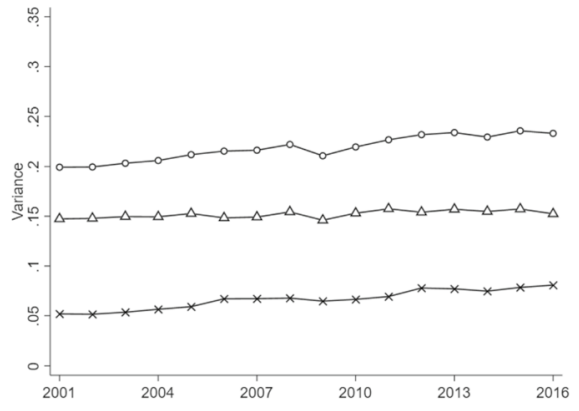

(a) Firms with fewer than 5,000 employees

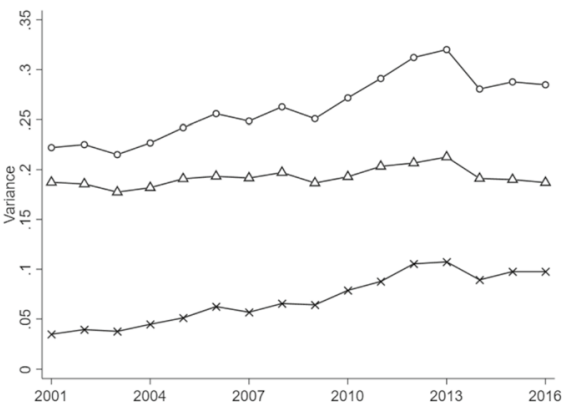

(b) Firms with more than 5,000 employees

Fig. 5 Variance decomposition by firm size. Note. These figures display the results of variance decomposition of Eq. (1) by firm size. (o) Overall wage variance $(\triangle)$ Within-firm variance; $(\times)$ Betweenfirm variance. I present results for firms with more than ten male employees and exclude individuals employed in public services and education

\section{A Detailed Decomposition of Wages}

\subsection{Econometric Model of Worker and Firm Fixed Effects}

The rising dispersion of wage differences between workers may be caused by two factors. First, rising dispersion of firm pay premiums may lead some firms to pay better wages and share more of their profits, while other firms do not. Indeed, several articles suggest that productivity differences between firms are responsible for increases in wage inequality (Faggio et al. 2010; Bloom et al. 2012; Andrews et al. 2016).

Second, the rising dispersion may be explained by changes in the worker composition of firms, that is, by changes in the sorting or the segregation of workers. High-ability workers may increasingly sort into highly productive firms, whereas the opposite holds for low-ability workers. A number of recent publications provide support for this claim (Håkanson et al. 2020; Bryson et al. 2016; Card et al. 2016; Bender et al. 2018; Bartolucci et al. 2018) ${ }^{14}$.

To estimate changes in worker and firm earnings, I follow the Card et al. (2013) implementation of the model, introduced by Abowd et al. (1999) and Abowd et al. (2002) (AKM). I divide the 2001-2016 period into two eight-year sub-periods and estimate a separate model for each sub-period. I consider the following linear model:

$$
y_{i, t}=X_{i, t} \beta+\theta_{i}+\psi_{J(i, t)}+\varepsilon_{i, t}
$$

where the dependent variable $y_{i, t}$ is the natural logarithm of the hourly wage rate of individual $i$ at time $t$. The matrix $X$ contains time-varying, exogenous characteristics of individual $i$, such as age, age squared, age cubed, year fixed effects, and a variable indicating whether (and how much) they work part-time. $\theta$, the worker fixed effect, captures earnings related to fixed worker characteristics (such as returns to

$\overline{14}$ See Card et al. (2018) for a detailed overview of the rent-sharing and wage determination literature. 


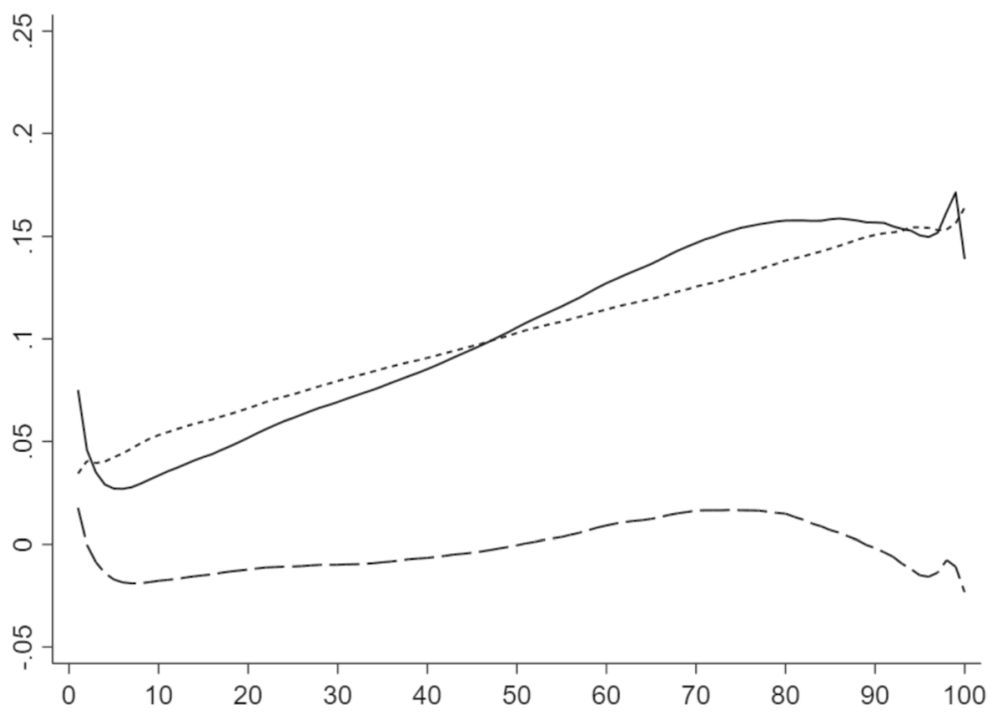

Fig. 6 Counterfactual distribution for changes due to within- or between-firm wage inequality only. NOTE. (-) Change in individual worker wages by percentile $(\cdots \cdots)$ Only between-firm inequality changes (- - ) Only within-firm inequality changes. I present results for firms with more than ten male employees and exclude individuals employed in public services and education

schooling or a worker's innate ability) and is constant over time. The function $J(i, t)$ on the subscript of $\psi$ is the firm fixed effect of individual $i$. The firm effect reflects the component of wages that is specific to the firm $J$, for instance, above or below the average compensation of workers of comparable skills that can be explained by firm-specific elements. The residual $\varepsilon_{i, t}$ captures transitory earnings fluctuations and contains a worker-firm specific match component.

The AKM model has been the standard for incorporating firm components into traditional earnings regressions. Although my model fits the data well, there are some well-known limitations. I follow Card et al. (2013) and empirically assess the plausibility of my model by considering all possible cases in which its assumptions may be violated. "Appendix B" presents the test results and addresses the limitations. Despite these limitations, my model is useful in helping to understand the patterns that I observe.

\subsection{Estimation Results}

Table 2 presents the estimation results of Eq. (3). I estimate Eq. (3) for two subperiods: $2001-2008$ and 2009-2016 ${ }^{15}$. Firm fixed effects are identified by the movements of workers between firms. To maximize the number of observations in the largest connected set, I do not impose any restrictions on firm size or industry, and

\footnotetext{
${ }^{15}$ I have also attempted to estimate the model with three sub-periods, but obtained larger standard errors as a result of lower mobility between firms.
} 
Table 2 Estimation results for AKM model by period

\begin{tabular}{lll}
\hline & $2001-2008$ & $2009-2016$ \\
\hline Sample Summary Statistics & & \\
\# Workers & $3,730,612$ & $3,695,707$ \\
\# Firms & 384,693 & 443,231 \\
Sample Size & $23,126,310$ & $22,630,213$ \\
Summary of Parameter Estimates & & \\
SD $(y)$ & 0.464 & 0.484 \\
SD $(\theta)$ & 0.390 & 0.420 \\
SD $(\psi)$ & 0.142 & 0.179 \\
SD $(X \beta)$ & 0.205 & 0.201 \\
Corr $(\theta, \psi)$ & 0.008 & 0.032 \\
Corr $(\theta$, X $\beta)$ & -0.168 & -0.203 \\
Corr $(\psi, X \beta)$ & -0.093 & -0.135 \\
Rmse(residual) & 0.180 & 0.157 \\
Adj. $R^{2}$ & 0.818 & 0.872 \\
Comparison Matching Model & & \\
Rmse(match residual) & 0.155 & 0.138 \\
Adj. $R^{2}$ & 0.849 & 0.894 \\
SD $($ match effect) & 0.418 & 0.462 \\
\hline Summary statistics for the estimation & & \\
\hline & & \\
\hline
\end{tabular}

Summary statistics for the estimation results of Eq. (3). $y=\log$ real hourly wage, $\theta=$ worker fixed effect, $\psi=$ firm fixed effect, $X \beta=$ observable wage component. All employed men aged 25-65 years in the 2001-2016 period are included. "Employed" is defined as having reported earnings that correspond to at least $90 \%$ of the Dutch minimum wage and having reported earnings that correspond to working at least thirteen 40-hour weeks or 520 hours per year for the year's minimum wage. Results reported are without restrictions on firm size

only impose these restrictions after the estimation. Table 2 presents the estimation results. In each period, I have approximately 23 million worker-year observations for about 3.7 million individual workers and 0.4 million firms in the largest connected set. I report several statistics to summarize my findings: the standard deviations of the worker and firm effect, the standard deviation of the time-variant worker components, their correlations as well as the adjusted $R^{2}$ and the root mean squared error (RMSE).

My results show that the standard deviation of wages remains relatively constant across the observation period. Person and firm wage components become more variable over time, while observable wage components become less variable over time. The correlation between worker and firm components increases slightly between period 1 and period 2, indicating an increase in the segregation of workers across establishments. The residual standard deviation (displayed as the RMSE) decreases slightly over time and the explanatory power of my model increases from period one to period two. I report an adjusted $R^{2}$ of 0.79 and 0.85 , respectively. 


\subsection{Variance Decomposition}

On the basis of the estimation results of Eq. (3), I decompose the variance of wages into within- and between-firm components. The variance in a given period can then be decomposed as follows:

$$
\begin{aligned}
\operatorname{Var}\left(y_{t}^{i, j}\right)= & \operatorname{Var}\left(\theta_{i}\right)+\operatorname{Var}\left(\psi_{J(i, t)}\right)+\operatorname{Var}\left(x_{i t}^{\prime} \beta\right) \\
& +2 \operatorname{Cov}\left(\theta, \psi_{J(i, t)}\right)+2 \operatorname{Cov}\left(\psi_{J(i, t)}, x_{i t}^{\prime} \beta\right) \\
& +2 \operatorname{Cov}\left(\theta_{i}, x_{i t}^{\prime} \beta\right)+\operatorname{Var}\left(\varepsilon_{i, t}\right)
\end{aligned}
$$

The components of interest are primarily the variance of person fixed effect $\left(\operatorname{Var}\left(\theta_{i}\right)\right)$, the variance of the firm fixed effect $\left(\operatorname{Var}\left(\psi_{J(i, t)}\right)\right)$, and the covariance of the worker and firm fixed effect $\left(\operatorname{cov}\left(\theta, \psi_{J(i, t)}\right)\right)$.

I interpret the first two components of the variance as the "widening skill premium" and "widening firm premium" that measure whether the variance of the worker or firm pay component have increased. The covariance component reflects worker sorting, namely whether high-wage workers sort into high-wage firms. The remaining components relate to the variance of time-varying worker characteristics and their covariance with worker and firm fixed effects ${ }^{16}$. The last term is the idiosyncratic wage component that is uncorrelated with all other components.

The decomposition in Eq. (4) does not allow for drawing conclusions on the relationship between changes in worker and firm earnings and changes in within- and between firm wage dispersion. To explain my findings from Sect. 5, the decomposition from Eq. (4) is rewritten as follows:

$$
\begin{aligned}
\operatorname{Var}\left(y_{t}^{i, j}\right) & =\underbrace{\operatorname{Var}\left(\bar{\theta}^{j}\right)+\operatorname{Var}\left(\psi^{j}\right)+2 \operatorname{Cov}\left(\bar{\theta}^{j}, \psi^{j}\right)}_{\text {Between-Firm-Variance }} \\
& +\underbrace{\operatorname{Var}\left(\theta^{i}-\bar{\theta}^{j}\right)+\operatorname{Var}\left(\varepsilon_{t}^{i, j}\right)}_{\text {Within-Firm-Variance }}
\end{aligned}
$$

The between-firm variance can be decomposed into three parts. Similar to the decomposition in Eq. (4), the variance of a firm's mean worker effect, $\operatorname{Var}\left(\bar{\theta}^{j}\right)$, relates to worker segregation and indicates whether low- and high-wage workers sort into different firms. The variance of firm effects, $\operatorname{Var}\left(\psi^{j}\right)$, measures if firm wage premiums have increased. Finally, the covariance of worker and firm effects, $\operatorname{Cov}\left(\bar{\theta}^{j}, \psi^{j}\right)$, reflects worker sorting.

The variance decomposition also includes the variance and covariance terms of time-varying worker characteristics, but I ignore these here for the same reason as

\footnotetext{
16 In practice, the interpretation of the covariance terms that contain the observable worker components proves difficult. For instance, the term $\operatorname{Cov}\left(\theta_{i}, x_{i t}^{\prime} \beta\right)$ could be interpreted as whether workers with a higher wage component, based on observable time varying characteristics, have a higher or lower wage, based on unobservable time-constant characteristics. There is little economic intuition concerning the sorting of workers based on their time varying and constant characteristics. Therefore, these terms are commonly not interpreted in the literature.
} 
discussed in footnote 16. For a detailed decomposition including these terms, see Eq. (6) in "Appendix C".

\subsection{Decomposition of the Changes in the Variance of Wages}

I now focus on the implications of my estimated model to explain the development of wage inequality in the Netherlands over time. Table 3 shows the individual components of the variance decomposition of Eq. (4) by period, as well as the change from period one (2001-2008) to period two (2009-2016).

In line with the literature, I find that wage inequality is primarily explained by unobservable worker characteristics. The variance of the worker fixed effect explains between $72 \%$ and $77 \%$ of the variance of wages. Other important components are the observable worker characteristics, as well as the residual, which account together for about $25 \%-32 \%$, followed by the covariance of worker and firm fixed effects, which accounts for $6 \%-10 \%$ of the variance. Firm-pay premiums only account for about $4 \%-5 \%$ of the variance of wages.

Focusing on the changes between the periods 2001-2008 and 2009-2016, it is observed that the increase of the variance of worker fixed effects accounts for almost the entire increase in wage inequality in the Netherlands. The second most important factor is the rise in the sorting of workers across firms, which accounts for $39 \%$ of the overall increase. Increases in the firm pay premium account for $13 \%$ of the change. Decreases in the variance of observable worker characteristics, and the residual as well as the covariance between worker fixed effects and observable characteristics have a negative effect on overall inequality.

I compare my findings with the results reported for Germany (Card et al. 2013), Italy (Devicienti et al. 2019), the Unites States (Song et al. 2019), and Sweden Håkanson et al. (2020). Card et al. (2013) note that increases in the firm component of wages account for $25 \%$ of the overall increase in wage inequality in Germany, whereas the majority of the rise in inequality (73\%) is explained by increasing returns to skills and by increases in the sorting of workers across firms. Similarly, Song et al. (2019) report that in the Unites States, the returns to the worker component $(68 \%)$ and the sorting component $(35 \%)$ are the two most important drivers, while the firm component has no considerable effect on wage inequality. Data from Italy differ significantly: worker sorting $(-42 \%)$ and the firm pay component $(-12 \%)$ decreased, while the returns to the unobservable- $(23 \%)$ and observablewage components $(19 \%)$ increased. Note that the increase in the covariance of the worker and firm component is similar across Germany (34\%), the United States (35\%) and the Netherlands (39\%). Håkanson et al. (2020) report an increase in the variance of of wages by $46 \%$ between 1986 and 2008 in Sweden, where increases in between firm wage variance explain $61 \%$ of the overall increase. About $45 \%$ of the increase in between-firm wage is accounted for by the combination of increased sorting by skill and increased returns to skill. 
Table 3 Decomposition of the rise in wage inequality

\begin{tabular}{|c|c|c|c|c|c|c|}
\hline & \multicolumn{2}{|l|}{ Interval 1} & \multicolumn{2}{|l|}{ Interval 2} & \multicolumn{2}{|c|}{ Change from } \\
\hline & \multicolumn{2}{|l|}{ (2001-2008) } & \multicolumn{2}{|l|}{$(2008-2016)$} & \multicolumn{2}{|l|}{1 to 2} \\
\hline & Comp. & Share & Comp. & Share & Comp. & Share \\
\hline $\operatorname{Var}(\mathrm{y})$ & 0.211 & & 0.233 & & 0.022 & \\
\hline $\operatorname{Var}(\theta)$ & 0.152 & 72.1 & 0.181 & 76.7 & 0.029 & 127.6 \\
\hline $\operatorname{Var}(\psi)$ & 0.009 & 4.1 & 0.012 & 5.2 & 0.003 & 13.4 \\
\hline $\operatorname{Var}(X \beta)$ & 0.038 & 17.9 & 0.035 & 15.3 & -0.002 & -10.9 \\
\hline $\operatorname{Var}(\varepsilon)$ & 0.030 & 14.0 & 0.023 & 10.1 & -0.007 & -29.1 \\
\hline $2 * \operatorname{Cov}(\theta, \psi)$ & 0.013 & 6.3 & 0.022 & 9.8 & 0.009 & 39.0 \\
\hline $2 * \operatorname{Cov}(\theta, X \beta)$ & -0.028 & -13.1 & -0.035 & -14.4 & -0.007 & -30.8 \\
\hline $2 * \operatorname{Cov}(\psi, X \beta)$ & -0.004 & -1.9 & -0.006 & -2.8 & -0.002 & -9.2 \\
\hline Worker-year observations & $15,652,271$ & & $15,093,480$ & & $-558,791$ & \\
\hline Firm-year observations & 271,198 & & 254,513 & & $-16,685$ & \\
\hline
\end{tabular}

This table presents the results of the variance decomposition of real log hourly wages from Eq. (4). y = $\log$ real hourly wage, $\theta=$ worker fixed effect, $\psi=$ firm fixed effect, $X \beta=$ observable wage component, $\varepsilon=$ residual. Only men aged 25-65 years are included in these statistics. Employed is defined as having reported earnings that correspond to at least $90 \%$ of the Dutch minimum wage and having reported earnings that correspond to working at least thirteen 40-hour weeks or 520 hours per year for the year's minimum wage. I present results for firms with more than ten male employees and exclude individuals employed in public services and education. The shares in columns three, five, and seven are computed by dividing the variance and covariance terms by the variance of wages

To connect my analysis to the descriptive evidence presented in Sect. 5, I present results for the variance decomposition of Eq. (5). Table 4 presents the results. Again, I observe that the between-firm component is responsible for most of the increase in wage inequality ${ }^{17}$.

Almost the entire increase in between-firm variance is caused by a rise in the variance of the mean worker effect and the covariance of worker and firm effects.

As the descriptive statistics in Fig. 1 in Sect. 1 show, the second interval between 2008 and 2016 is characterized by an erratic pattern. Hence, the strong increase in the standard deviation of worker fixed effects, as shown in Table 3, and in the variance of worker fixed effects, as shown in Table 4, between period 1 and period 2, are presumably due to job destruction caused by the Great Recession. This observation can also be made when considering the development of particular industries as shown in Table 6, which suggests that a decrease in the employment share often goes hand in hand with an increasing variance of the worker fixed effect, for example the financial or manufacturing sector, perhaps because of job destruction in the middle-segment during the second time interval.

I repeat the same exercise as above with the sample divided by firm size. Table 5 shows that the between-firm component now accounts for $72 \%$ and $79 \%$

\footnotetext{
17 My results slightly deviate from those reported in Sect. 5. This is due to differences in sample composition. While I compare yearly means in Fig. 4, I compare the means of Period 1 (2001-2008) and Period 2 (2009-2016). However, in terms of magnitude and direction, they confirm the observation I made in Sect. 5.
} 


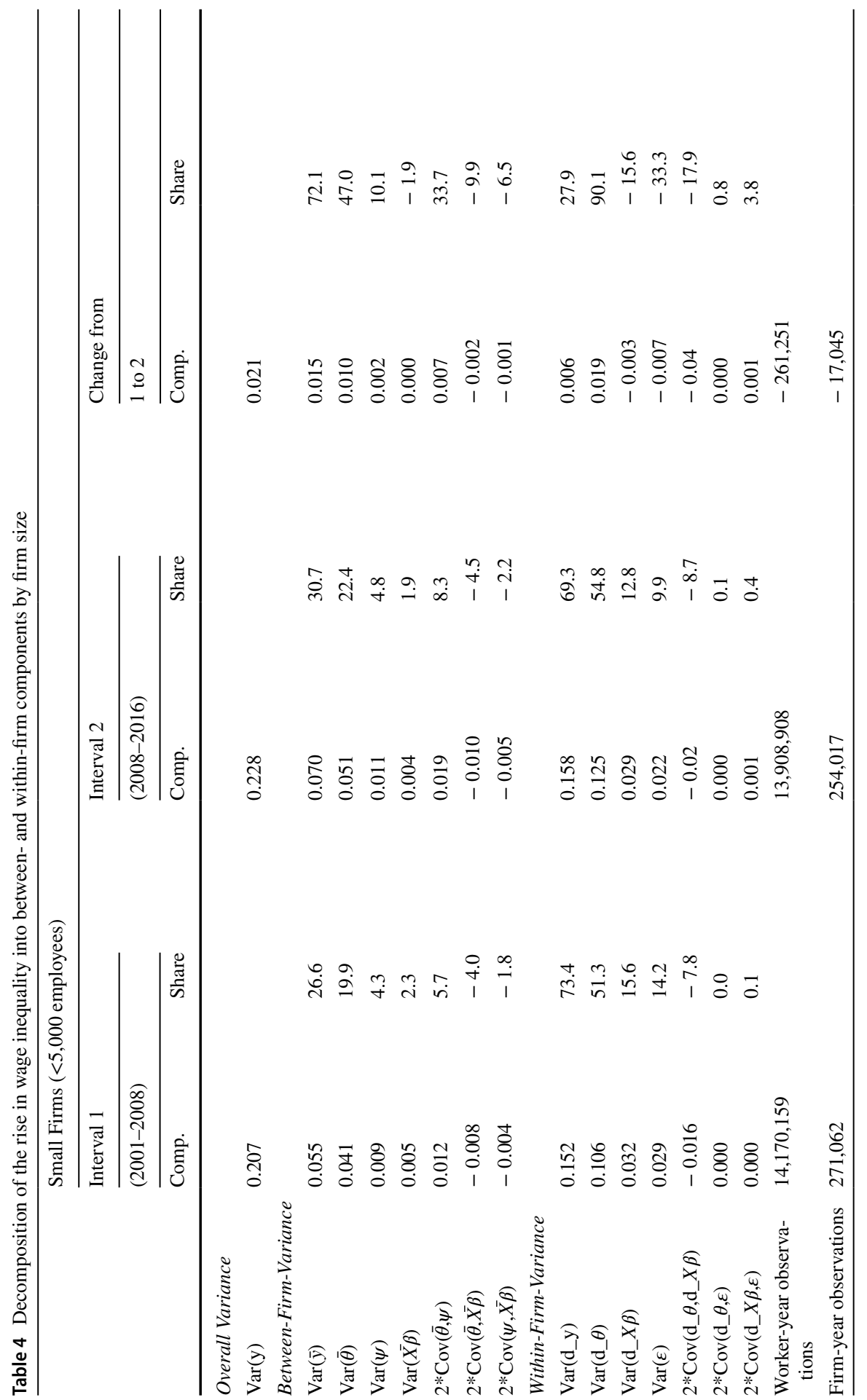




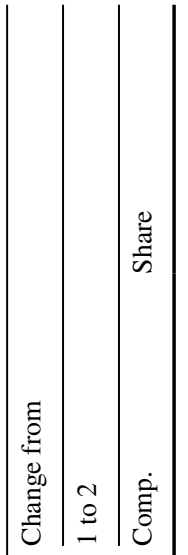

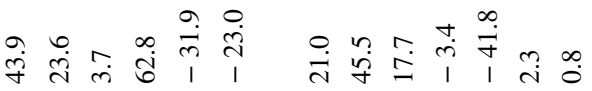

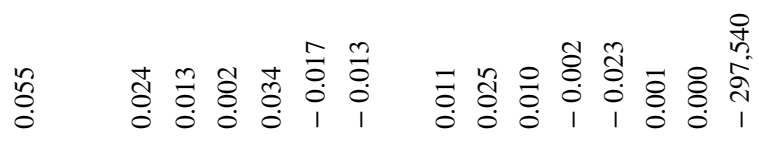

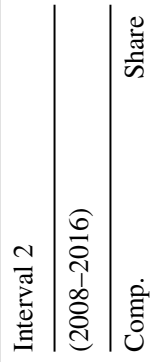

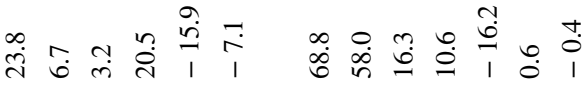

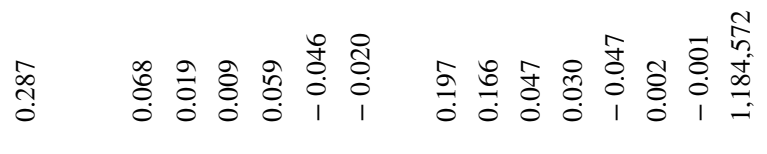

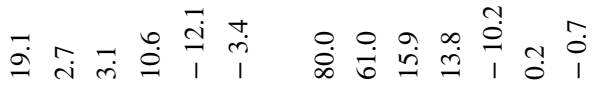

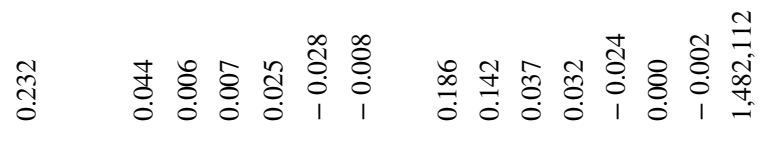

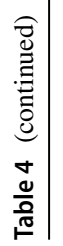

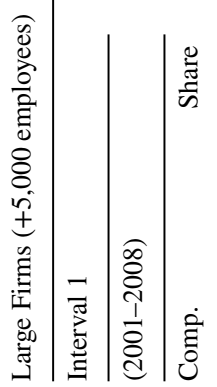

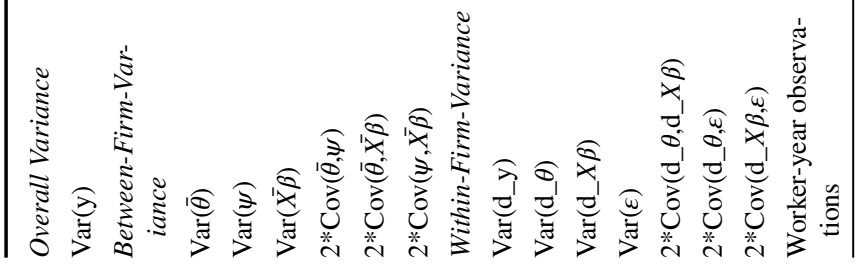




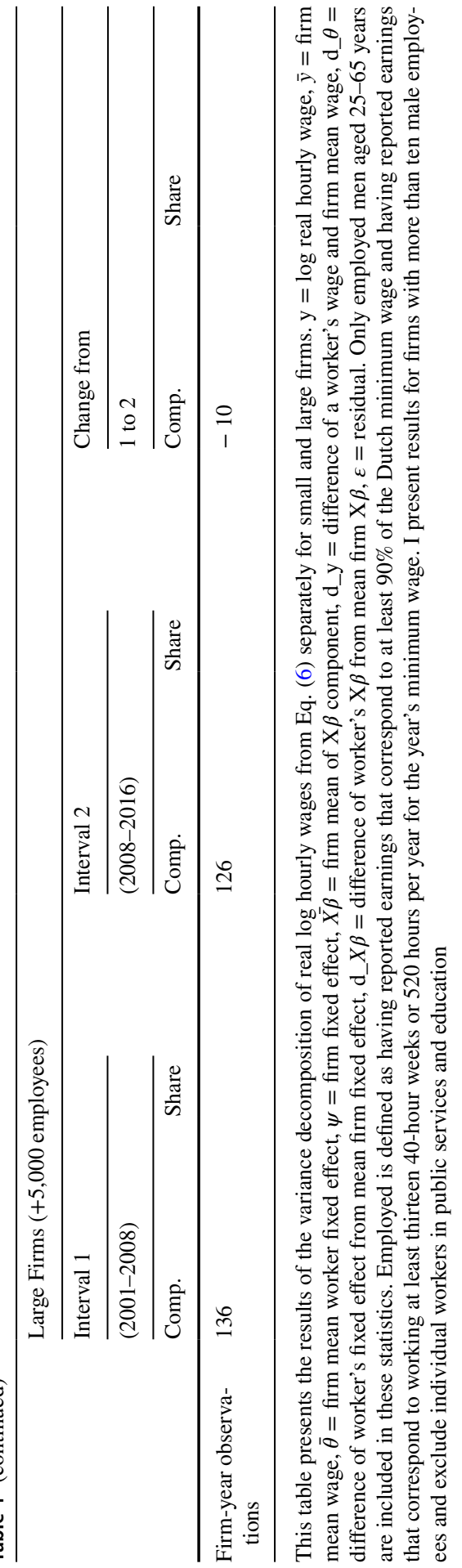


Table 5 Decomposition of the rise in wage inequality into between- and within-firm components

\begin{tabular}{|c|c|c|c|c|c|c|}
\hline & \multirow{2}{*}{\multicolumn{2}{|c|}{$\frac{\text { Interval } 1}{(2001-2008)}$}} & \multirow{2}{*}{\multicolumn{2}{|c|}{$\frac{\text { Interval } 2}{(2008-2016)}$}} & \multirow{2}{*}{\multicolumn{2}{|c|}{$\frac{\text { Change from }}{1 \text { to } 2}$}} \\
\hline & & & & & & \\
\hline & Comp. & Share & Comp. & Share & Comp. & Share \\
\hline \multicolumn{7}{|l|}{ Overall Variance } \\
\hline $\operatorname{Var}(y)$ & 0.211 & & 0.233 & & 0.022 & \\
\hline \multicolumn{7}{|l|}{ Between-Firm-Variance } \\
\hline $\operatorname{Var}(\bar{y})$ & 0.056 & 26.3 & 0.072 & 31.0 & 0.017 & 74.8 \\
\hline $\operatorname{Var}(\bar{\theta})$ & 0.042 & 20.1 & 0.052 & 22.5 & 0.010 & 45.0 \\
\hline $\operatorname{Var}(\psi)$ & 0.009 & 4.1 & 0.012 & 5.0 & 0.003 & 13.4 \\
\hline $\operatorname{Var}(\overline{X \beta})$ & 0.005 & 2.4 & 0.005 & 2.1 & 0.000 & -0.6 \\
\hline $2 * \operatorname{Cov}(\bar{\theta}, \psi)$ & 0.013 & 6.3 & 0.022 & 9.5 & 0.009 & 39.0 \\
\hline $2 * \operatorname{Cov}(\bar{\theta}, \bar{X} \beta)$ & -0.010 & -4.7 & -0.013 & -5.5 & -0.003 & -12.7 \\
\hline $2 * \operatorname{Cov}(\psi, \bar{X} \beta)$ & -0.004 & -1.9 & -0.006 & -2.6 & -0.002 & -9.2 \\
\hline \multicolumn{7}{|l|}{ Within-Firm-Variance } \\
\hline $\operatorname{Var}\left(\mathrm{d} \_y\right)$ & 0.155 & 73.7 & 0.161 & 69.0 & 0.006 & 25.2 \\
\hline $\operatorname{Var}\left(\mathrm{d} \_\theta\right)$ & 0.110 & 52.0 & 0.128 & 55.0 & 0.018 & 82.6 \\
\hline $\operatorname{Var}\left(\mathrm{d} \_X \beta\right)$ & 0.033 & 15.5 & 0.030 & 13.1 & -0.002 & -10.3 \\
\hline $\operatorname{Var}(\varepsilon)$ & 0.030 & 14.0 & 0.023 & 9.9 & -0.007 & -29.1 \\
\hline $2 * \operatorname{Cov}\left(\mathrm{d} \_\theta, \mathrm{d} \_X \beta\right)$ & -0.017 & -8.0 & -0.022 & -9.4 & -0.055 & -22.6 \\
\hline $2 * \operatorname{Cov}\left(\mathrm{d} \_\theta, \varepsilon\right)$ & 0.000 & 0.1 & 0.000 & 0.2 & 0.000 & 1.0 \\
\hline $2 * \operatorname{Cov}\left(\mathrm{d} \_X \beta, \varepsilon\right)$ & 0.000 & 0.0 & 0.001 & 0.4 & 0.001 & 3.5 \\
\hline Worker-year observations & $15,652,271$ & & $15,093,4$ & & $-558,791$ & \\
\hline Firm-year observations & 271,198 & & 254,513 & & $-16,685$ & \\
\hline
\end{tabular}

This table presents the results of the variance decomposition of real log hourly wages from Eq. (6). y = $\log$ real hourly wage, $\bar{y}=$ firm mean wage, $\bar{\theta}=$ firm mean worker fixed effect, $\psi=$ firm fixed effect, $\bar{X} \beta$ $=$ firm mean of $X \beta$ component, $d \_y=$ difference of a worker's wage and firm mean wage, $d \_\theta=$ difference of worker's fixed effect from mean firm fixed effect, $\mathrm{d} \_X \beta=$ difference of worker's $X \beta$ from mean firm $\mathrm{X} \beta, \varepsilon=$ residual. I present results for firms with more than ten male employees and exclude workers employed in public services and education. The shares in columns three, five, and seven are computed by dividing the variance and covariance terms by the variance of wages

of overall inequality in small and large firms, respectively. Furthermore, about half of this share is observed to be accounted for by an increase in the dispersion of worker fixed effects (47\% for small and $44 \%$ for large firms). Overall, the increase in wage dispersion appears to be more distinct in large firms than in smaller firms, which is consistent with my analysis in Sect. 4.

I also consider differences in the development of wage inequality across industries in explaining the overall trend. Results are reported in "Appendix C'. I observe some interesting developments, for instance, an increase in the employment share of human health and social work activities and a decrease in the employment share of manufacturing. However, the main patterns that were observed previously, a rise in the covariance of the worker and firm effects and a rise in the variance of worker effects, also take place within major sectors. Thus, 
I conclude that the pattern observed is not driven by industry composition, but rather by changes within sectors.

In summary, I find that the increase in the between-firm wage component is largely driven by an increase in the variance of the average worker effect (45\%), that is, an increase in worker segregation; an increase in the covariance of the worker and firm effect (39\%), or in other words, in worker sorting; and increases in firmspecific wage effects (13\%). Thus, the majority of the increase in wage dispersion is explained by changes in worker composition across firms.

\section{What Explains Higher Between-Firm Inequality?}

\subsection{Changes in the Workforce Composition of Firms Over Time}

In Sect. 4, I document that changes between firms account for nearly the entire increase in overall wage dispersion. In Sect. 6, I show that changes in the composition of workers across firms, caused by increases in worker sorting and worker segregation, lead to increasing differences in the average wages between firms. What is responsible for these changes?

Here, I provide some illustrative evidence that shows - in line with the findings reported in the earlier sections of this paper - similar patterns for the distribution of skills across firms as measured by the level of education. I focus on changes in the distribution of educational degrees across firms and divide firms into deciles based on the average wage they pay and then compute changes in the shares of male employees between 2001 and 2016 by education level. I consider various educational levels: lower secondary, upper secondary, and bachelor's, master's, and $\mathrm{PhD}$ degrees ${ }^{18}$.

Figure 7 presents the results. I observe that the share of workers with low and medium levels of education disproportionally increases at low-wage firms and decreases in high-wage firms. Conversely, the share of workers with high levels of education decreases in low-wage firms and increases in high-wage firms. This is apparent for bachelor's, but especially so for master's and PhD degrees. The share of workers with college-level education has been decreasing in the bottom $70 \%$ of firms and increasing in the top $30 \%$ of firms and may reflect the increase in worker sorting that was documented in Sect. 6.4.

It appears that the increase in the demand for skills is particularly pronounced among the science, technology, engineering, and medicine (STEM) fields, and similar to the sorting by educational level, I observe a distinct pattern for educational

\footnotetext{
18 Levels of education follow the OECD (2012) International Standard Classification of Education (ISCED) classification. Lower secondary education corresponds to a level of education at best equivalent to lower secondary education (ISCED 0-2) and upper secondary education, to upper secondary education (ISCED 3-4). Bachelor's degree corresponds to a level equivalent to a first tertiary degree (ISCED 5-6) and master's degree, to a second tertiary degree (ISCED 7). PhD corresponds to ISCED code 8. I present results for firms with more than ten male employees and exclude individuals in public services and education.
} 


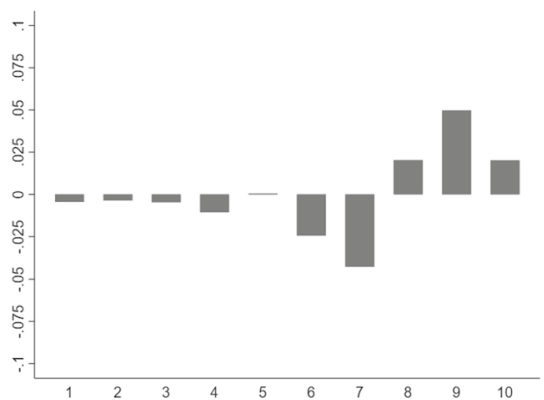

(a) Life sciences

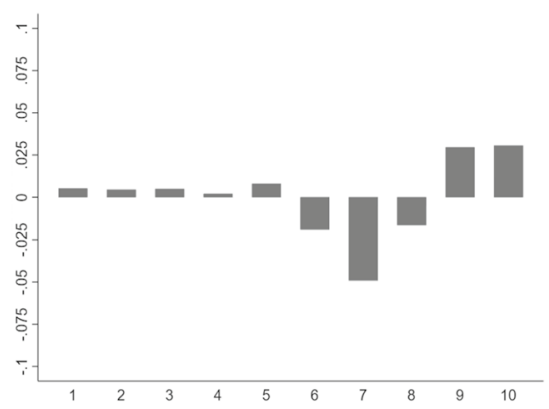

(c) Mathematics and Statistics

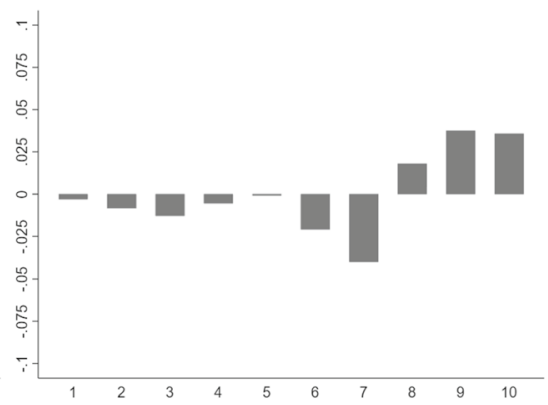

(b) Physical sciences

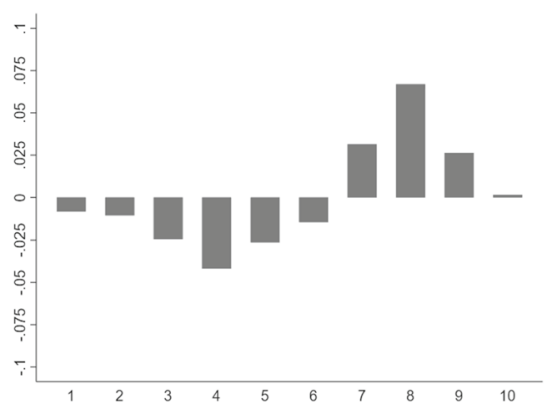

(d) Environmental sciences

Fig. 7 Changes in the distribution of workers across firm mean wage deciles by educational field. NOTE. This table displays changes in the distribution of male workers by educational field across firm mean wage deciles between 2001 and 2016. I compute mean wage deciles on the basis of firm average wages by period. The classification of educational fields follow the 2-digit ISCED field-of-study codes: 42 for Life sciences, 44 for Physical sciences, 46 for Mathematics and Statistics, and 85 for Environmental sciences

degrees in the STEM fields ${ }^{19}$. I repeat the same exercise as in Fig. 8 but now compute changes in the shares of employees by educational field. In this regard, I follow the 2-digit ISCED field of study codes, which allows me to differentiate between 25 different fields of education. I find a distinct pattern for STEM fields ${ }^{20}$. I observe that the share of workers in lower wage establishments decreases, while their share in high-wage firms increases. For instance, the share of workers with a degree in Physical science or Mathematics and Statistics increases by about 2.5 percentage points in the highest-paying firms across my observation period.

My results are similar to those reported by Spitz-Oener (2006), Goos and Manning (2007), Goos et al. (2009), Akcomak et al. (2013), Michaels et al. (2014), and

\footnotetext{
${ }^{19}$ I also observe this pattern for several other educational fields, i.e., architecture, journalism, law, health and veterinary medicine.

20 Life sciences correspond to ISCED-field 42, Physical sciences, to ISCED-field 44, Mathematics and Statistics, to ISCED-field 46, and the Environmental sciences, to ISCED-field 85.
} 


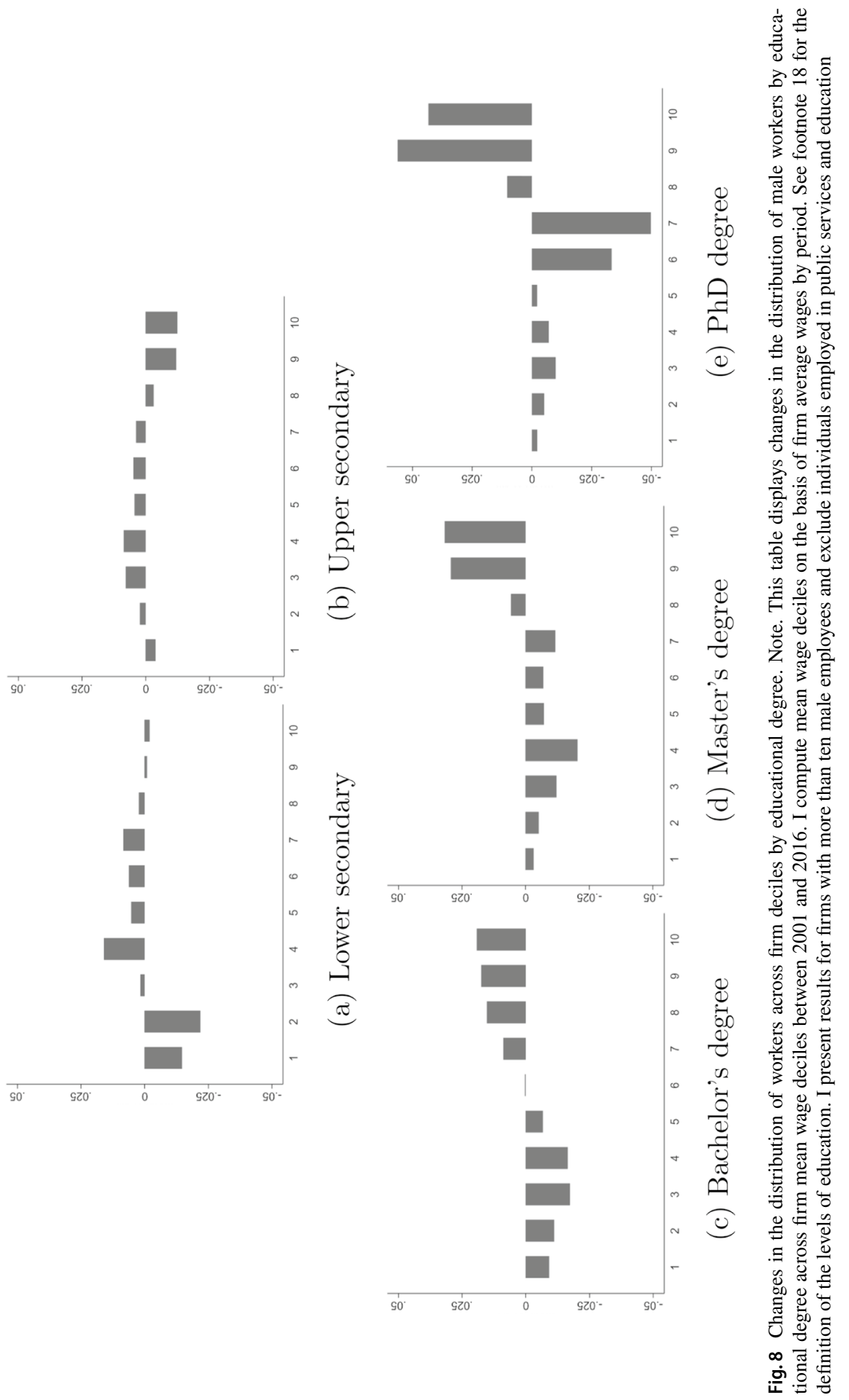


Goos et al. (2014) and indicate a pattern of polarization of the labor market. Job polarization over the past 30 years has been characterized by a shift in the employment structure. The number of jobs at the top of the skill ladder has grown, while jobs at the middle of the distribution have disappeared and have been absorbed by an increasing share of low-paid personal service jobs (Autor 2015; Beaudry et al. 2016). Technological change is considered a major explanation for this phenomenon (Autor et al. 2003). Recent technological change is biased toward replacing routine tasks $^{21}$. As such, technological change leads to an increase in the relative demand for skilled jobs (that are abundant in non-routine cognitive tasks), as well as an increase in the demand for low-skilled jobs (that are typically abundant in non-routine manual skills), because these jobs cannot easily be automated, and results in a decrease in the relative demand of middle-skilled jobs, which are typically characterized by routine manual and cognitive skills. This process appears to be structural rather than cyclical (Modestino et al. 2019; Blair and Deming 2020), and became apparent especially after the Great Recession, which employers used to shift the composition of new hires toward higher-skilled workers.

\subsection{Labor Market Institutions}

Increases in wage inequality as well as decreases in unionization rates and coverage of collective agreements are two parallel trends that characterize many industrialized economies over the past few decades. Several authors point out that labor market institutions, such as unions and the minimum wage, mitigate increases in wage inequality, particularly at the bottom of the wage distribution and that recent increases in wage inequality cannot be explained by changes in tasks performed at the workplace alone (Dustmann et al. 2009; Antonczyk et al. 2009; Fitzenberger et al. 2011; Antonczyk et al. 2010).

For instance, Dustmann et al. (2009) argue that technological change is mainly responsible for changes at the top of the wage distribution, while declines in union coverage better explain changes at the bottom of the wage distribution. More specifically, they find that $28 \%$ of the increase in lower tail wage dispersion ${ }^{22}$ is caused by a decline in union coverage compared to an increase of $11 \%$ at the top of the wage distribution ${ }^{23}$.

In Germany, the share of employees covered by collective agreements decreased from more than $70 \%$ in 1985 to less than 30\% in 2008. Opt-out clauses enable firms to deviate from industry-wide collective agreements by negotiating firm-level agreements. These agreements are predominantly based on contracts and mutual

\footnotetext{
${ }^{21}$ Routine tasks refer to tasks that are codifiable and can be expressed by rules. Non-routine tasks, in contrast, are complementary to technology and include, for instance, well-paid professional and managerial occupations.

${ }^{22}$ Lower tail wage dispersion is measured as the difference between the $50 \%$ and the $15 \%$ percentile of $\log$ wages.

${ }^{23}$ Upper tail wage dispersion is measured as the difference between the $85 \%$ and the $50 \%$ percentile of log wages.
} 
agreements between employer associations, trade unions, and work councils and are not based on legislative reforms. In this regard, Card et al. (2013) show that the increase in the dispersion of wage premiums is much stronger for firms not covered by collective bargaining status. A substantial fraction of these firms is in the lowest two deciles of the firm fixed effect distribution. According to Dustmann et al. (2014), flexibility and decentralization have played an important role in the favorable evolution of the German economic performance in the second half of the 2000s, although at the cost of increases in wage inequality. More recent evidence provided by Baumgarten et al. (2020) points in the same direction. The authors show that the decline in collective bargaining is one of the main sources of increased wage dispersion in Germany.

In contrast, Devicienti et al. (2019) report that firms in Italy have been unable to apply such heterogeneous pay policies. Italy's system of industrial relations shares many similarities to the German one, the main difference, however, is the binding nature of industry-wide collective agreements. According to the authors, this explains why wage inequality has remained relatively flat since the 2000s and why increases in wage dispersion occurred almost entirely between, but not within, different job titles, that are bound to statutory minimum wages.

This descriptive evidence suggests that labor market institutions and the system of industrial relations play an important role in mediating overall wage inequality. In the Netherlands, collective bargaining coverage has remained relatively constant over the 2001-2016 period. Unfortunately, the data do not permit any further investigation of these factors, since I do not have access to worker-level information on this. Expanding the analysis to investigate the effects of labor market institutions, including collective agreements and minimum wages, could explain the attenuated increase in wage dispersion in comparison to other industrialized countries, especially to Germany, and should prove to be a promising field for further research.

\section{Conclusion}

In this article, I analyzed trends in wage inequality in the Netherlands. Wage dispersion increased from 2001-2016 and was almost entirely driven by changes in average wages between firms, even more so in large firms. My results suggest that worker segregation increased and high-wage workers increasingly tend to work together with high-wage coworkers. I then examined possible sources of the rise in between-firm wage dispersion. I estimated a two-level fixed effects model and used the estimated components to decompose changes in the variance of wages. Increases in wage dispersion were found to be mainly explained by a rise in the variance of skills and increases in worker sorting and worker segregation. This implies that highwage workers tend to work with high-wage coworkers, but also increasingly cluster in high-wage firms, while the opposite holds for low-wage workers. This pattern was also apparent when examining the distribution of educational degrees. Shares of highly educated individuals, especially at the master's or $\mathrm{PhD}$ level increased in high-wage firms and decreased in medium- and low-wage firms. 
The evidence of my variance decomposition is quantitatively comparable to other industrialized economies. However, the main difference is that wage inequality increased at a much lower rate in the Netherlands. Recent literature suggests that labor market institutions, mainly the coverage of collective bargaining outcomes, is inversely related to wage inequality. This could be one of the reasons that the increases in wage dispersion were comparatively small in the Netherlands. Strong institutions, characterized by constant levels of collective coverage and increases in real minimum wages, may be effective tools in counteracting increases in wage inequality.

\section{Appendix A: Simulation of Counterfactual Distribution}

I estimate the counterfactual distributions as follows. I start with data restricted to firms with more than ten (observable) male employees, excluding organizations active in public services or education. I then calculate the yearly firm mean wage. On the basis of firm mean wages, I construct 100 equally sized percentiles $f$ and then sort individuals into these bins. As such, individuals in a given firm are typically in the same bin. Next, for each percentile $f, 250$ individual wage bins $i$ are created on the basis of the individual wage. This yields 25,000 firm-individual bins, $f i$. For instance, assume that $f=50$ and $i=200$. This indicates that firms pay wages between the 49th and 50th percentile, whereas the individual log wage within the firm is between the 79.6th and 80th percentile.

In year $t$, the mean log wage of the firm-individual percentile $f i$ is denoted as $\bar{w}_{t f i}$. $\bar{w}_{t f}$ denotes mean log wages for firm bin $f$. The difference $d_{t f i}$ between firm-individual and firm bins is computed as $d_{t f i}=\bar{w}_{t f i}-\bar{w}_{t f}$.

On the basis of these measures, I am now able to simulate various counterfactual distributions. I start by simulating the actual data for the years 2001 and 2016, to determine how well the simulated data fit the real data. I compute the counterfactual as $c_{f i}^{t, t}=d_{t f i}+\bar{w}_{t f}$ for all $f i$. This yields 25,000 data points, which I sort into 100 percentiles. I then calculate the mean value of $c_{f i}^{t, t}$ per percentile. The difference between the actual and simulated data can then be calculated as the difference between the mean value of $c_{f}^{t, t}$ per percentile minus the mean wage for the actual percentile of the wage distribution in year $t$. My results for the years 2001 and 2016 are shown in Fig. 9. I observe only small differences between actual and simulated values. For instance, the simulated mean hourly wage for the 50th percentile in 2016 corresponds to a value of $€ 21.8394$ while the actual value for the 50th percentile corresponds to $€ 21.8349$.

To construct the counterfactual distribution for constant between- or within-firm wage inequality, I proceed as follows: I start with the distribution that would prevail if between firm wage dispersion remained at levels observed in year 2001, but within firm wage dispersion changed to the level observed in year 2016. This can be computed as $c_{f i}^{2001,2016}=d_{2001, f i}+\bar{w}_{2016, f}$. Likewise, I can simulate the wage distribution if within firm wage dispersion stayed constant and between-firm wage dispersion increased to 2016 levels: $c_{f i}^{2016,2001}=d_{2016, f i}+\bar{w}_{2001, f}$. For both calculations, 25,000 


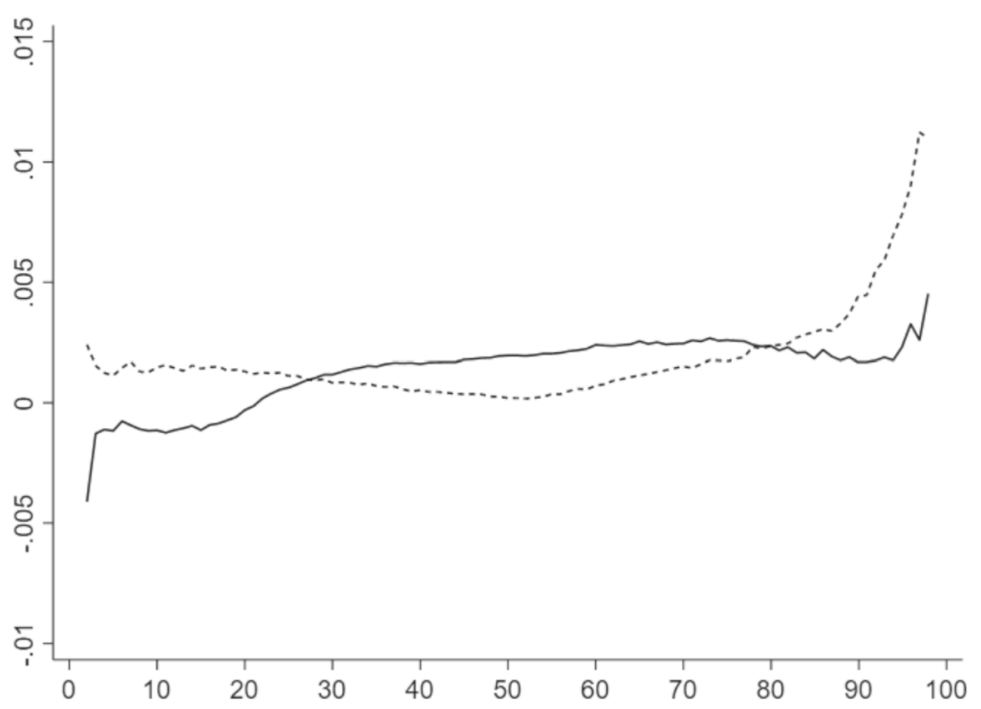

Fig. 9 Counterfactual residuals. Note. $(\cdots \cdots)$ Residual 2001 ( $(-)$ Residual 2016. Each point in the graph shows the difference in average log wages by percentile between the actual wages and the simulated values simulated values by year. I present results for firms with more than ten male employees and exclude individuals employed in public services and education

values are obtained again, and are sorted into 100 percentiles. Then, the mean per percentile is computed and compared to the actual distribution in 2016. Figure 6 displays the results. The dashed line displays the distribution had between dispersion remained constant, and the dotted line the distribution had within dispersion remained constant.

Figure 9 shows the difference in average log wages by percentile between the actual wages and the simulated values for the years 2001 and 2016. It shows that my simulations are accurate, with deviations being relatively close to zero across percentiles.

\section{Appendix B: Testing for the Assumptions of the Two-Way Fixed Effects Model}

Mobility between firms is crucial, because otherwise, person and firm effects cannot be identified. A connected set contains all firms that any employee ever worked for and all employees that ever worked for a company within the set. Job mobility is identified by moves of workers between the firms in the connected set ${ }^{24}$. The first step to test the assumptions of the two-way fixed effects model is to estimate connected groups of workers and employers. My sample is one large connected

\footnotetext{
${ }^{24}$ See Cornelissen (2008) for a detailed description of the computation of worker mobility and connected sets.
} 
group, and less than $1.9 \%$ of the observations are disconnected. Therefore, I only use the largest group for my analysis. In the second period, 2009-2016, my group thus contains 22,630,213 distinct firm-worker pairs, 3,727,689 unique workers, and 443,231 unique firms. With regard to worker mobility, $54.4 \%$ of workers in my sample changed employers at least once within the observation period.

Identifying the parameters of interest via OLS requires the assumption that conditional on worker and firm effects, job moves do not depend systematically on other components. This assumption is often referred to as the conditional endogenous mobility assumption. Its relationship to economic models of worker mobility is extensively discussed in Abowd et al. (1999) and Card et al. (2013). To ensure my findings are plausible, I follow Card et al. (2013) and assess all cases in which this assumption may be violated.

First, endogenous mobility is present if sorting is based on the idiosyncratic match component of wages. This form of sorting implies that at a given establishment, different workers have different wage premiums based on their matching component. I test for this violation by adding a dummy variable to Eq. (3) for each job match and compare it to my baseline estimation. Table 2 shows the results. The table shows an overview of the basic findings and statistics. In terms of magnitude, my main results are comparable to Song et al. (2019). The basic fit of the model is good with an adjusted $R^{2}$ of 0.85 and an RMSE of 0.17 in period 2. To check whether adding a match component would substantially increase the fit of my model, I compare it to the match model. The match model has a lower RMSE and a higher $R^{2}$, but overall improvement is relatively small (adjusted $R^{2}=0.88$, RMSE $=0.15$ ). This is in line with the Card et al. (2013)'s interpretation that match effects represent uncorrelated random effects.

I provide further evidence on the appropriateness of the basic AKM specification by examining average regression residuals for different groups of worker and firm effects. Violations of the separability assumptions ${ }^{25}$ can cause large mean residuals for some matches, for instance, when highly skilled workers are matched to low-wage establishments or vice versa. I follow Card et al. (2013) and divide the estimated person and establishment effects in each interval into deciles and compute the mean residual in each of the 100-person firm decile cells. Figure 10a and b show the mean residuals for each decile. Mean residuals are relatively small across cells (below 0.01) and show no systematic pattern. Residuals appear larger only for the cells with low worker or low firm effects, especially for the first observation period. The results are similar to those reported by Card et al. (2013) (Figure VI) for Germany and Song et al. (2019) (Figure 14a) and the United States, who report larger mean residuals for the lowest worker and firm effect groups. My data appear to be a good description for all worker and firm groups, with the exception of the bottom and top end.

Second, workers could select jobs based on their matching component. If this is the case, then wage patterns for movers would be different from wage losses. Following Card et al. (2013), I perform an event-study to analyze the effect of job

\footnotetext{
25 The separability assumptions presumes that $\log$ wages are additively separable into a worker and a firm component.
} 


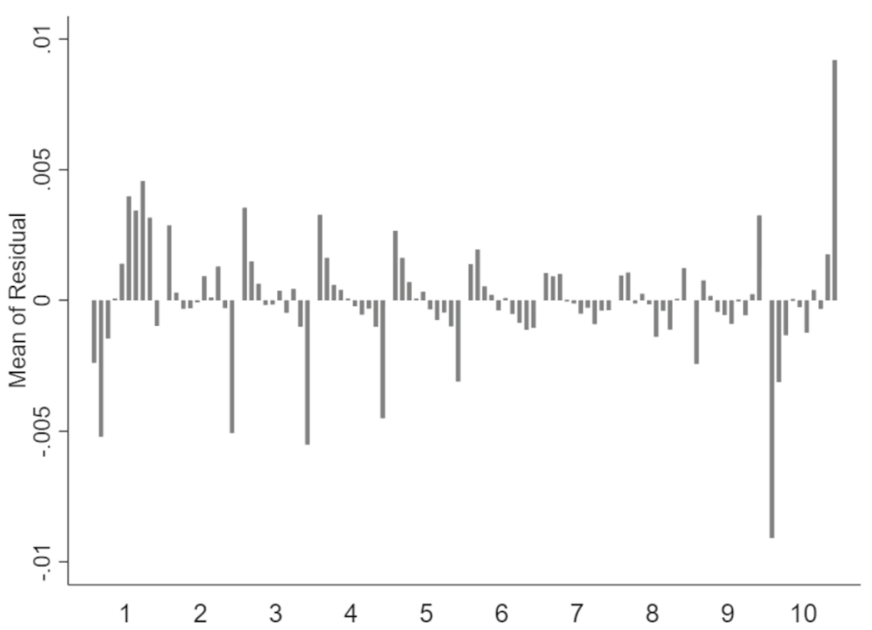

(a) 2001-2008

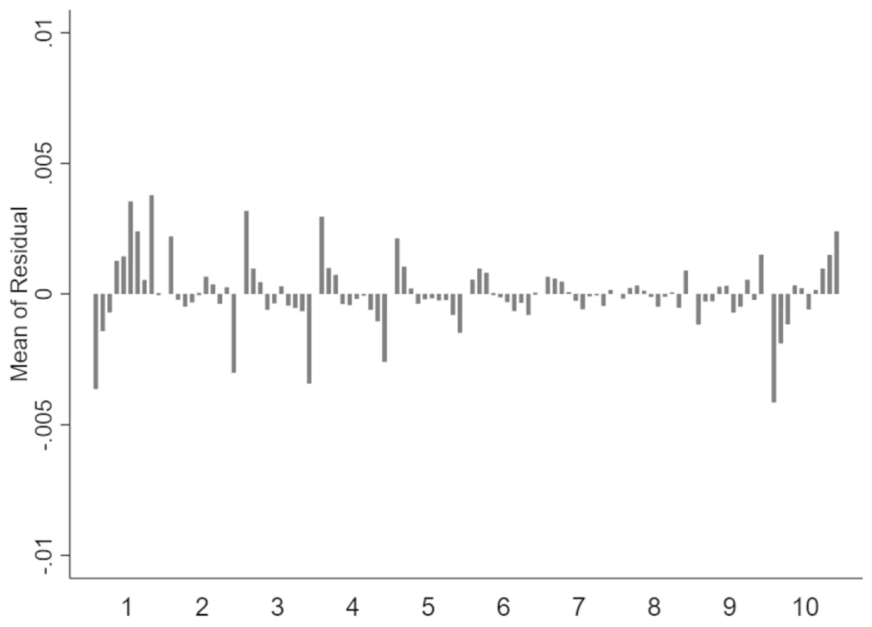

(b) 2009-2016

Fig. 10 Residuals by firm fixed effect deciles. NOTE. All employed male workers aged 25-65 years in the 2001-2016 period are included. "Employed" is defined as having reported earnings that correspond to at least $90 \%$ of the Dutch minimum wage and having reported earnings that correspond to working at least thirteen 40-hour weeks or 520 hours per year for the year's minimum wage. The results reported for the estimation of the sample are without restrictions on firm size or industry

mobility on earnings. I divide firms into quartiles based on their average wages. Thereafter, I calculate mean changes in earnings of workers moving between the four firm-type classes in the years before and after the job change. I consider workers as movers if they held a job at least two years preceding and following 


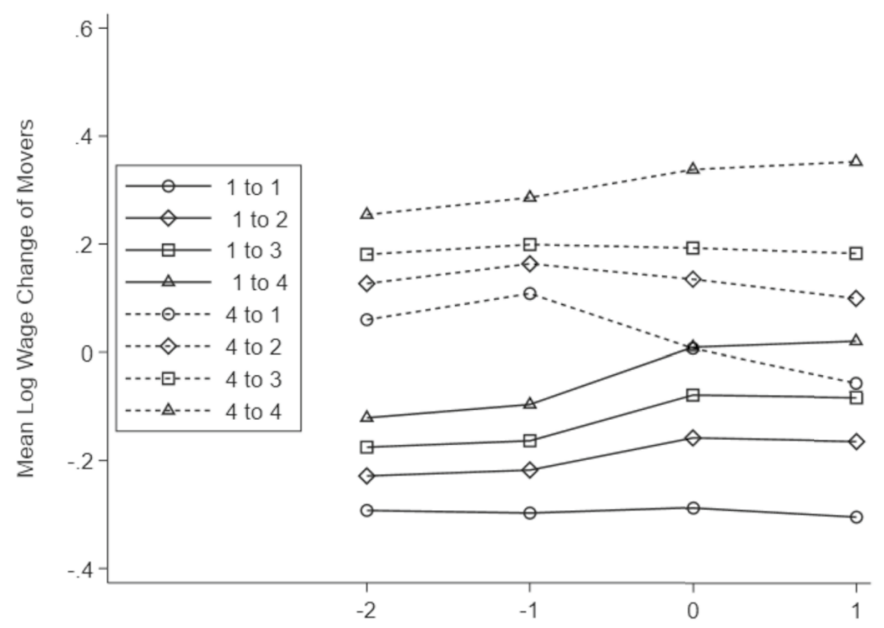

(a) 2001-2008

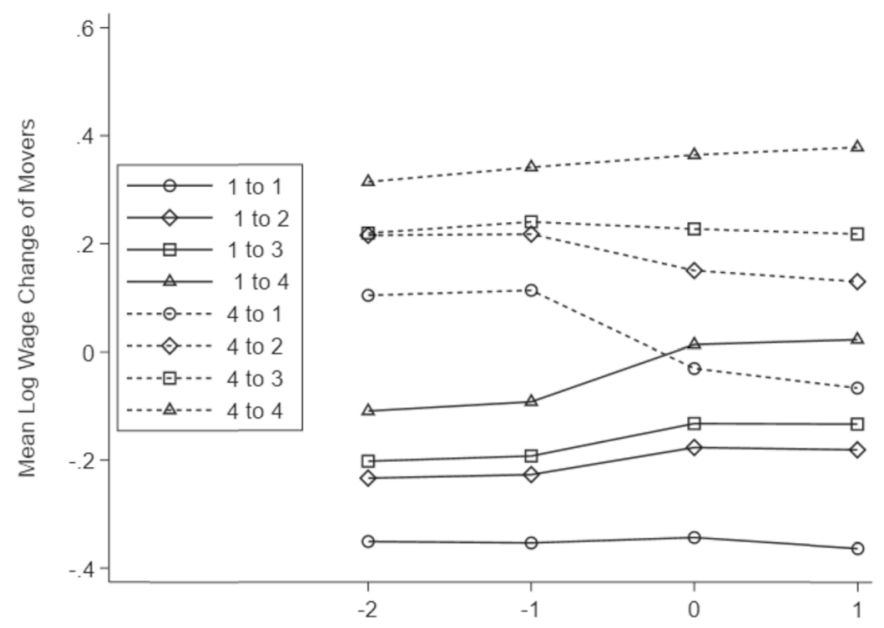

(b) 2009-2016

Fig. 11 Mean wage changes of job movers departing from quartile 1 and 4 of mean firm wage at the origin and destination firms NOTE. All employed male workers aged 25-65 years in the 2001-2016 period are included. "Employed" is defined as having reported earnings that correspond to at least $90 \%$ of the Dutch minimum wage and having reported earnings that correspond to working at least thirteen 40-hour weeks or 520 hours per year for the year's minimum wage. The results reported for the estimation of the sample are without restrictions on firm size or industry. The figure shows the mean wage change of job movers for the 2001-2016 period. Movers held the job at least two years preceding and following their job change

the job change. For every job move, I have the exact dates of workers' departure in the old firm and arrival in the new firm. Mean firm wages on the old job are calculated based on the coworkers' mean wages in the last year at that job, while 


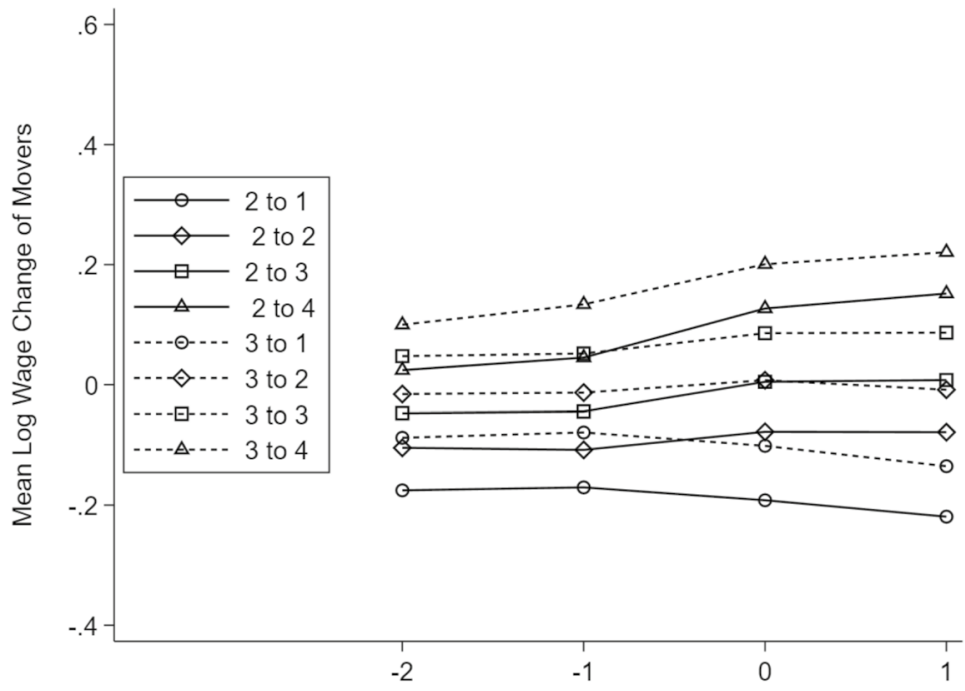

(a) 2001-2008

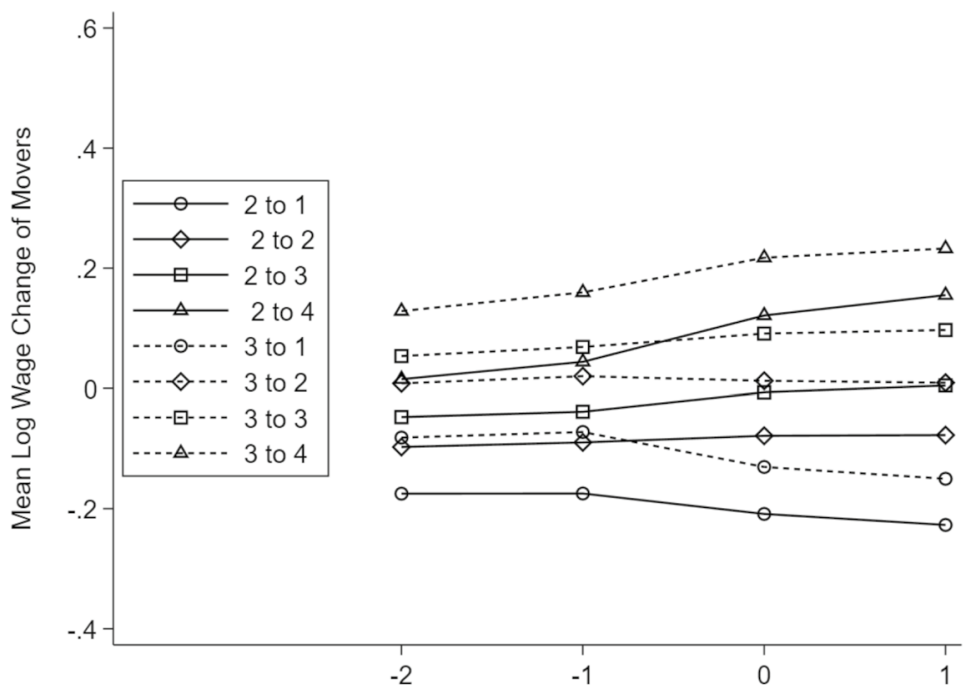

(b) 2009-2016

Fig. 12 Mean wage changes of job movers departing from quartile 2 and 3 of mean firm wage at the origin and destination firms. NOTE. All employed male workers aged 25-65 years in the 2001-2016 period are included. "Employed" is defined as having reported earnings that correspond to at least $90 \%$ of the Dutch minimum wage and having reported earnings that correspond to working at least thirteen 40-hour weeks or 520 hours per year for the year's minimum wage. The results reported for the estimation of the sample are without restrictions on firm size or industry. The figure shows the mean wage change of job movers for the 2001-2016 period. Movers held the job at least two years preceding and following their job change 


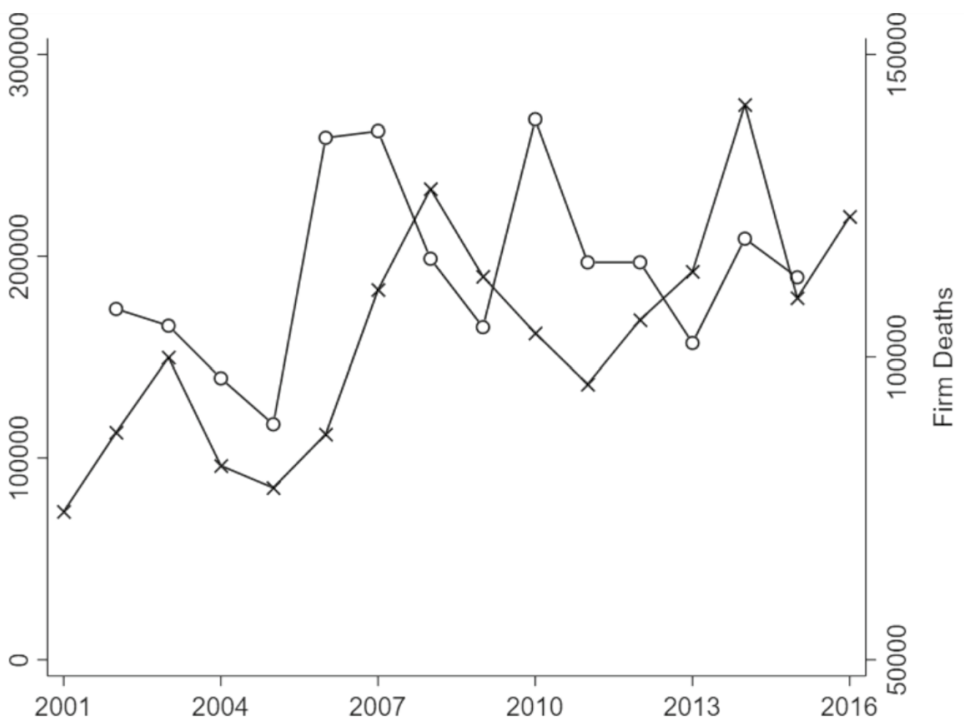

Fig. 13 Number of yearly job changes and firm deaths. NOTE. The results reported for the estimation of the sample are without restrictions on firm size or industry. The figure displays the number of yearly job changes between 2002 and 2015 denoted as (o) on the left y-axis and the number of yearly firm deaths denoted as $(\times)$ on the right $y$-axis for the years 2001-2016. All employed male workers aged 25-65 years in the 2001-2016 period are included. "Employed" is defined as having reported earnings that correspond to at least $90 \%$ of the Dutch minimum wage and having reported earnings that correspond to working at least thirteen 40-hour weeks or 520 hours per year for the year's minimum wage. Movers held the job at least two years preceding and following their job change. Data of firm deaths is based on the General Business Register ('1 'Algemeen Bedrijven Register”, ABR)

mean firm wages on the new job are based on coworkers' mean wages in the first year on that job. Job movers can then be classified into 16 cells based on the origin and destination firm and the difference in wages in the years before and after the job change is calculated. Figure 11a and b displays the mean log wage difference between the old and new job by period. I observe that wages for movers at the different points of the distribution differ before and after the move. Wage changes for workers moving from quartile 1 to quartile 4 jobs are different from wage changes of workers who move from quartile 4 to quartile 1 jobs. In line with the results of Card et al. (2013), I find symmetric wage losses and wage gains for workers moving from high- to low-paying firms and the reverse. The same symmetric pattern of wage gains and losses is observed for job movers departing from quartiles 2 and 3 as shown by Fig. 12a and b. Overall, my model delivers a good approximation of the underlying earnings process.

Unfortunately, my data does not allow to distinguish between voluntary and involuntary job changes. Because of the effects of the Great Recession, job mobility in the second interval (2009-2016) may be involuntarily more often in comparison to the first interval (2001-2008) and may therefore lead to larger wage drops, especially because of strict employment protection in the Netherlands that 
leads to high returns to tenure, which is lost upon displacement (Deelen et al. 2018). However, I argue that distinguishing between voluntary and involuntary job changes does not matter with regards to the results of my analysis, for three reasons. First, as shown in Fig. 13, the number of job changes is relatively stable across time and is higher previous to the Great Recession. Although the number of job changes spikes in 2009, the same can be observed for the years 2006 and 2007. Second, the number of firm deaths spikes in 2008, decreases and then increases again from 2011 onwards. Third, Figs. 11a, b and 12a, b do not show different patterns between the intervals. Hence, I argue that if any trend biases the estimation of worker and firm fixed effects it is present in both periods and should affect results equally.

Another form of endogenous mobility arises when the drift component $\zeta_{i, t}$ predicts job changes. For instance, workers who are less productive than expected will earn less and are more likely to move to lower-wage firms. However, the absence of trends prior to a job transition for workers who transit to higher- or lower-wage firms cannot explain the patterns observed, as shown in Fig. 11a and b.

Finally, endogenous mobility may be present if the transitory error is correlated with systematic movements between high- and low-wage workplaces. In this case, workers who experience a negative wage shock when moving to a new firm are more likely to move to lower wage firms. However, as previously discussed, there is sparse evidence that mobility patterns are related to the transitory error term. All findings seem to support my orthogonality assumption. Hence, the use of OLS is appropriate.

\section{Appendix C: Detailed Variance Decomposition into Between- and Within-Firm Components}

See Table 6. 


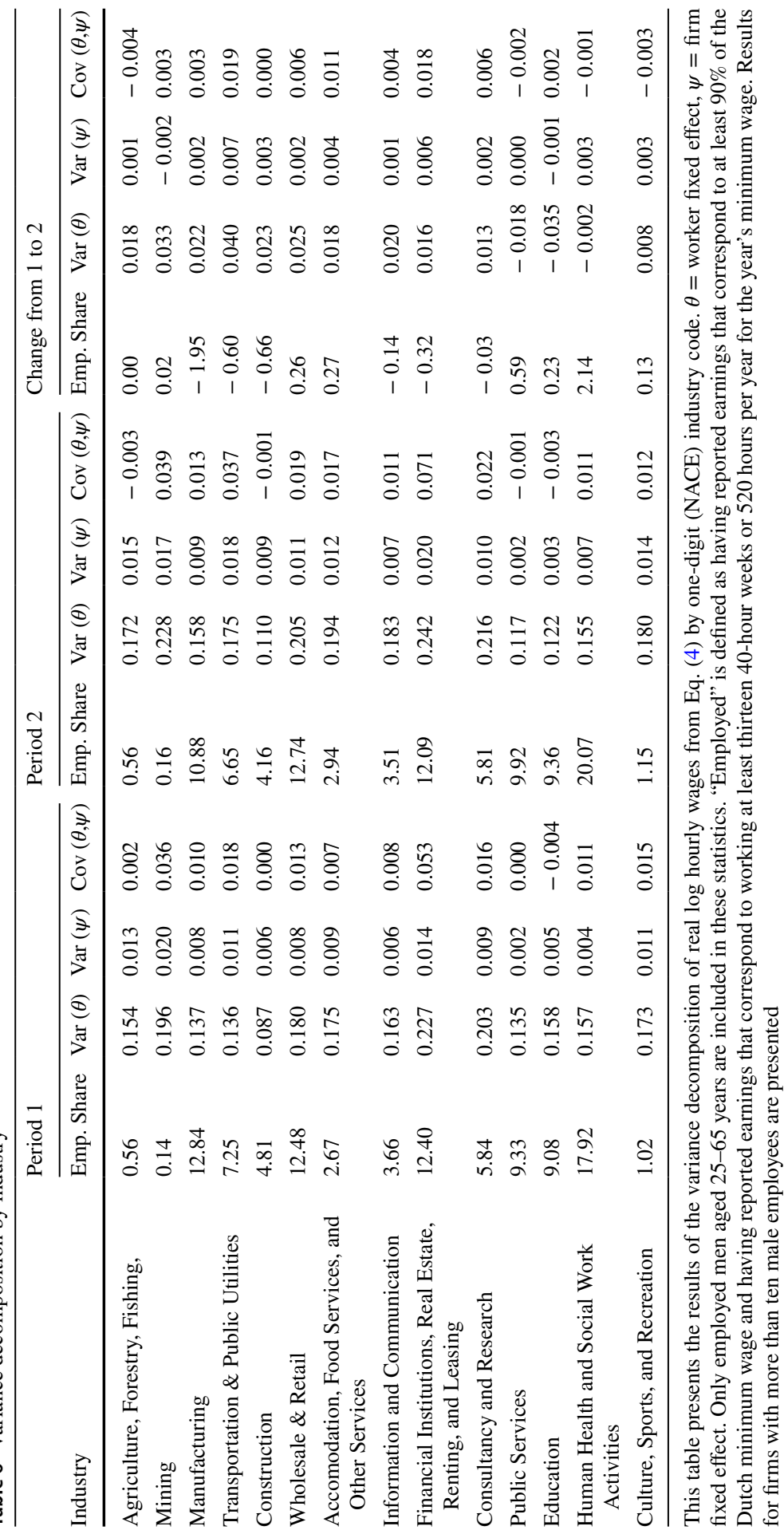




$$
\begin{aligned}
\operatorname{Var}\left(y_{t}^{i, j}\right) & =\underbrace{\operatorname{Var}\left(\bar{y}^{j}\right)+\operatorname{Var}\left(\bar{\theta}^{j}\right)+\operatorname{Var}\left(\psi^{j}\right)+\operatorname{Var}\left(\bar{x}^{\prime} \beta^{j}\right)}_{\text {Between-Firm-Variance }} \\
& +\frac{\operatorname{Cov}\left(\bar{\theta}^{j}, \psi^{j}\right)+2 \operatorname{Cov}\left(\bar{\theta}, \bar{x}^{j}\right)+2 \operatorname{Cov}\left(\psi^{j}, \bar{x} \beta^{j}\right)}{\operatorname{Var}\left(\theta^{i}-\bar{\theta}^{j}\right)+\operatorname{Var}\left(x_{i t}^{\prime} \beta-x^{\bar{\prime}} \beta^{j}\right)} \\
& +\underbrace{\operatorname{Var}\left(y^{i}-\bar{y}^{j}\right)+\operatorname{Vov}\left(\theta^{i}-\bar{\theta}^{j}, x_{i t}^{\prime} \beta-x^{\prime} \beta^{j}\right)}_{\text {Within-Firm-Variance }} \\
& +\underbrace{\operatorname{Var}\left(\varepsilon_{t}^{i, j}\right)+2 \operatorname{Cov}\left(x_{i t}^{\prime} \beta-x^{\prime} \beta^{j}, \varepsilon_{t}^{i, j}\right)}
\end{aligned}
$$

Open Access This article is licensed under a Creative Commons Attribution 4.0 International License, which permits use, sharing, adaptation, distribution and reproduction in any medium or format, as long as you give appropriate credit to the original author(s) and the source, provide a link to the Creative Commons licence, and indicate if changes were made. The images or other third party material in this article are included in the article's Creative Commons licence, unless indicated otherwise in a credit line to the material. If material is not included in the article's Creative Commons licence and your intended use is not permitted by statutory regulation or exceeds the permitted use, you will need to obtain permission directly from the copyright holder. To view a copy of this licence, visit http://creativecommons.org/licen ses/by/4.0/.

\section{References}

Abowd, J., Kramarz, F., \& Margolis, D. N. (1999). High wage workers and high wage firms. Econometrica, 67(2), 251-333.

Abowd, J. M., Creecy, R. H., Kramarz, F. et al. (2002). Computing person and firm effects using linked longitudinal employer-employee data. Technical report, Center for Economic Studies, US Census Bureau

Acemoglu, D. (1998). Why do new technologies complement skills? Directed technical change and wage inequality. The Quarterly Journal of Economics, 113(4), 1055-1089.

Acemoglu, D., \& Autor, D. (2011). Skills, tasks and technologies: Implications for employment and earnings. In Handbook of Labor Economics, (vol. 4, pp. 1043-1171). Elsevier: Amsterdam

Akcomak, S., Kok, S., Rojas-Romagosa, H. et al. (2013). The effects of technology and offshoring on changes in employment and task-content of occupations. Technical report, CPB Netherlands Bureau for Economic Policy Analysis.

Andrews, D., Criscuolo, C., \& Gal, P. N. (2016). The best versus the rest: the global productivity slowdown, divergence across firms and the role of public policy. $O E C D$.

Antonczyk, D., Fitzenberger, B., \& Leuschner, U. (2009). Can a Task-Based Approach Explain the Recent Changes in the German Wage Structure? Journal of Economics and Statistics, 229(2-3), 214-238. 
Antonczyk, D., Fitzenberger, B., \& Sommerfeld, K. (2010). Rising wage inequality, the decline of collective bargaining, and the gender wage gap. Labour Economics, 17(5), 835-847.

Atkinson, A. B., \& Salverda, W. (2005). Top Incomes in the Netherlands and the United Kingdom over the 20th Century. Journal of the European Economic Association, 3(4), 883-913.

Autor, D. (2015). Why are there still so many jobs? the history and future of workplace automation. The Journal of Economic Perspectives, 29(3), 3-30.

Autor, D., Levy, F., \& Murnane, R. J. (2003). The skill content of recent technological change: An empirical exploration. The Quarterly Journal of Economics, 118(4), 1279-1333.

Autor, D. H., Katz, L. F., \& Kearney, M. S. (2008). Trends in US wage inequality: Revising the revisionists. The Review of Economics and Statistics, 90(2), 300-323.

Autor, D. H., Dorn, D., \& Hanson, G. H. (2015). Untangling trade and technology: Evidence from local labour markets. The Economic Journal, 125(584), 621-646.

Bartolucci, C., Devicienti, F., \& Monzón, I. (2018). Identifying sorting in practice. American Economic Journal: Applied Economics, 10(4), 408-38.

Baumgarten, D., Felbermayr, G., \& Lehwald, S. (2020). Dissecting between-plant and within-plant wage dispersion: Evidence from germany. Industrial Relations: A Journal of Economy and Society, 59(1), $85-122$.

Beaudry, P., Green, D. A., \& Sand, B. M. (2016). The great reversal in the demand for skill and cognitive tasks. Journal of Labor Economics, 34(S1), S199-S247.

Bender, S., Bloom, N., Card, D., Van Reenen, J., \& Wolter, S. (2018). Management practices, workforce selection, and productivity. Journal of Labor Economics, 36(S1), S371-S409.

Blair, P. Q., \& Deming, D. J. (2020). Structural increases in demand for skill after the great recession. In AEA Papers and Proceedings, (vol. 110, pp. 362-65).

Bloom, N., Sadun, R., \& Van Reenen, J. (2012). Americans do it better: US multinationals and the productivity miracle. The American Economic Review, 102(1), 167-201.

Bryson, A. J., Freeman, R. B., Barth, E., \& Davis, J. C. (2016). It's where you work: Increases in earnings dispersion across establishments and individuals in the US. Journal of Labor Economics, 34(S2), S57-S97.

Card, D., \& DiNardo, J. E. (2002). Skill-biased technological change and rising wage inequality: Some problems and puzzles. Journal of Labor Economics, 20(4), 733-783.

Card, D., Heining, J., \& Kline, P. (2013). Workplace heterogeneity and the rise of West German wage inequality. The Quarterly Journal of Economics, 128(3), 967-1015.

Card, D., Cardoso, A. R., \& Kline, P. (2016). Bargaining, sorting, and the gender wage gap: Quantifying the impact of firms on the relative pay of women. The Quarterly Journal of Economics, 131(2), 633-686.

Card, D., Cardoso, A. R., Heining, J., \& Kline, P. (2018). Firms and labor market inequality: Evidence and some theory. Journal of Labor Economics, 36(S1), S13-S70.

Cornelissen, T. (2008). The stata command felsdvreg to fit a linear model with two high-dimensional fixed effects. Stata Journal, 8(2), 170.

CPB. Centraal Economisch Plan (CEP) (2017). Technical report, CPB Netherlands Bureau for Economic Policy Analysis, 2017.

CBS Netherlands. Consumer Prices in the Netherlands. URL https://ec.europa.eu/eurostat/cache/metad ata/Annexes/htec_esms_an8.pdf.

David, H., Dorn, D., \& Hanson, G. H. (2013). The China syndrome: Local labor market effects of import competition in the United States. American Economic Review, 103(6), 2121-2168.

Davis, S. J., \& Haltiwanger, J. (1991). Wage dispersion between and within us manufacturing plants, 1963-1986. Technical report, National Bureau of Economic Research.

Deelen, A., de Graaf-Zijl, M., \& van den Berge, W. (2018). Labour market effects of job displacement for prime-age and older workers. IZA Journal of Labor Economics, 7(1), 3.

Delsen, L., \& Poutsma, E. (2005). Labour market institutions and economic performance in the Netherlands. International Economic Journal, 19(2), 169-196.

Devicienti, F., Fanfani, B., \& Maida, A. (2019). Collective bargaining and the evolution of wage inequality in Italy. British Journal of Industrial Relations, 57(2), 377-407.

Dustmann, C., Ludsteck, J., \& Schönberg, U. (2009). Revisiting the german wage structure. The Quarterly Journal of Economics, 124(2), 843-881.

Dustmann, C., Fitzenberger, B., Schönberg, U., \& Spitz-Oener, A. (2014). From sick man of europe to economic superstar: Germany's resurgent economy. Journal of Economic Perspectives, 28(1), $167-88$. 
Faggio, G., Salvanes, K. G., \& Van Reenen, J. (2010). The evolution of inequality in productivity and wages: panel data evidence. Industrial and Corporate Change, 19(6), 1919-1951.

Fitzenberger, B., Kohn, K., \& Wang, Q. (2011). The erosion of union membership in germany: determinants, densities, decompositions. Journal of Population Economics, 24(1), 141-165.

Goos, M., \& Manning, A. (2007). Lousy and lovely jobs: The rising polarization of work in Britain. The Review of Economics and Statistics, 89(1), 118-133.

Goos, M., Manning, A., \& Salomons, A. (2009). Job polarization in Europe. The American Economic Review, 99(2), 58-63.

Goos, M., Manning, A., \& Salomons, A. (2014). Explaining job polarization: Routine-biased technological change and offshoring. The American Economic Review, 104(8), 2509-2526.

Groot, S. P. T., \& Groot, H. L. F. (2011). Wage inequality in the Netherlands: Evidence, trends and explanations. CPB Discussion Paper 186.rdf, CPB Netherlands Bureau for Economic Policy Analysis.

Håkanson, C., Lindqvist, E., \& Vlachos, J. (2020). Firms and skills: The evolution of worker sorting. Journal of Human Resources. https://doi.org/10.3368/jhr.56.2.0517-8801R2

Hartog, J., \& Salverda, W. (2018). The labor market in the Netherlands, 2001-2016. IZA World of Labor, (418).

Helpman, E., Itskhoki, O., Muendler, M.-A., \& Redding, S. J. (2017). Trade and inequality: From theory to estimation. The Review of Economic Studies, 84(1), 357-405.

Juhn, C., Murphy, K. M., \& Pierce, B. (1993). Wage inequality and the rise in returns to skill. Journal of Political Economy, 101(3), 410-442.

Katz, L. F., \& Murphy, K. M. (1992). Changes in relative wages, 1963-1987: supply and demand factors. The Quarterly Journal of Economics, 107(1), 35-78.

Lee, D. S. (1999). Wage inequality in the United States during the 1980s: Rising dispersion or falling minimum wage? The Quarterly Journal of Economics, 114(3), 977-1023.

Michaels, G., Natraj, A., \& Van Reenen, J. (2014). Has ICT polarized skill demand? Evidence from eleven countries over twenty-five years. Review of Economics and Statistics, 96(1), 60-77.

Modestino, A. S., Shoag, D., \& Ballance, J. (2019). Upskilling: Do employers demand greater skill when workers are plentiful? Review of Economics and Statistics, 102(4), 793-805.

OECD. Education at a glance 2012. Technical report, Organisation for Economic Co-operation and Development, 2012.

OECD (2020a) Labor force statistics by sex and age. Technical report, Organisation for Economic Cooperation and Development, (2020a). data retrieved from OECD Labor Force Statistics - Sex and Age composition, https://stats.oecd.org/Index.aspx?DataSetCode=LFS_SEXAGE_I_R\#.

OECD (2020b). Labor force statistics - trade unions and collective bargaining. Technical report, Organisation for Economic Co-operation and Development, (2020b). data retrieved from OECD Labor Force Statistics - Trade Unions and Collective Bargaining, https://stats.oecd.org/Index.aspx?DataS etCode=TUD\#.

Song, J., Price, D. J., Guvenen, F., Bloom, N., \& Von Wachter, T. (2019). Firming up inequality. The Quarterly Journal of Economics, 134(1), 1-50.

Spitz-Oener, A. (2006). Technical change, job tasks, and rising educational demands: Looking outside the wage structure. Journal of Labor Economics, 24(2), 235-270.

Ter Weel, B. (2003). The Structure of Wages in the Netherlands, 1986-98. Labour, 17(3), 361-382.

Teulings, C., \& Hartog, J. (1997). Corporatism or competition: An international comparison of labour market structures and their impact on wage formation.

Van den Berge, W., Erken, H., de Graaf-Zijl, M., \& Van Loon, E. (2014). The Dutch labour market during the Great Recession. Technical report, CPB Netherlands Bureau for Economic Policy Analysis. 